\title{
DETERMINANTS AND CONSEQUENCES OF BARGAINING POWER IN HOUSEHOLDS
}

\author{
Leora Friedberg and Anthony Webb
}

\author{
CRR WP 2006-13 \\ Released: June 2006 \\ Draft Submitted: May 2006 \\ Center for Retirement Research at Boston College \\ 550 Fulton Hall \\ 140 Commonwealth Ave. \\ Chestnut Hill, MA 02467 \\ Tel: 617-552-1762 Fax: 617-552-1750 \\ http://www.bc.edu/crr
}

\begin{abstract}
* Leora Friedberg is a professor of economics at the University of Virginia. Anthony Webb is a research economist at the Center for Retirement Research at Boston College. The findings and conclusions are solely those of the authors and do not represent the views of the University of Virginia or Boston College. We would like to thank Federico Ciliberto, Maxim Engers, John Pepper, and especially Steven Stern, and participants of workshops at the University of Virginia, the Society of Labor Economics, Harvard University, and UNC-Greensboro for their extremely helpful comments, and especially Jonathan King for excellent research assistance. Any remaining errors are our own.
\end{abstract}

(C) 2006, by Leora Friedberg and Anthony Webb. All rights reserved. Short sections of text, not to exceed two paragraphs, may be quoted without explicit permission provided that full credit, including (C notice, is given to the source. 


\section{About the Center for Retirement Research}

The Center for Retirement Research at Boston College, part of a consortium that includes a parallel centers at the University of Michigan and the National Bureau of Economic Research, was established in 1998 through a grant from the Social Security Administration. The goals of the Center are to promote research on retirement issues, to transmit new findings to the policy community and the public, to help train new scholars, and to broaden access to valuable data sources. Through these initiatives, the Center hopes to forge a strong link between the academic and policy communities around an issue of critical importance to the nation's future.

\section{Center for Retirement Research at Boston College \\ 550 Fulton Hall \\ 140 Commonwealth Ave. \\ Chestnut Hill, MA 02467 \\ phone: 617-552-1762 fax: 617-552-0191 \\ e-mail: crr@bc.edu \\ http://www.bc.edu/crr}

\section{Affiliated Institutions:}

American Enterprise Institute

The Brookings Institution

Center for Strategic and International Studies

Massachusetts Institute of Technology

Syracuse University

Urban Institute 


\begin{abstract}
A growing literature offers indirect evidence that the distribution of bargaining power within a household influences decisions made by the household. These results undermine the notion that a household can be treated as a "unitary" decision maker. The indirect evidence links household outcomes to variables that are assumed to influence the distribution of bargaining power within the household. In this paper, we have data on whether a husband or wife in the Health and Retirement Study "has the final say" when making major decisions in a household. We use this variable to analyze determinants and some consequences of bargaining power. Our analysis overcomes endogeneity problems arising in many earlier studies and constitutes the missing link confirming the importance of household bargaining models.

We find that decision-making power depends on plausible variables within the household and also influences important household outcomes, and moreover that the second set of results is much stronger than the first set. While current and lifetime earnings significantly affect decision-making power, the effects are moderate. On the other hand, decision-making power has important effects on financial decisions like stock market investment and total wealth accumulation and may help explain, for example, the relatively high poverty rate among widows. Thus, our results suggest that more research into the determination of bargaining power is needed, and that household bargaining has major effects on the welfare of household members.
\end{abstract}




\section{Introduction}

A growing literature offers indirect evidence that the distribution of bargaining power within a household influences decisions made by the household. Yet, earlier papers were not able to measure actual bargaining power. We use information from a unique question in the Health and Retirement Study to analyze the determinants and some consequences of bargaining power.

Models of household bargaining have two important implications for understanding individual outcomes. First, the welfare of household members depends on the distribution of bargaining power. Second, household decisions are not the outcome of a single individual maximizing utility. Indirect evidence against "unitary" decision-making links household outcomes to variables that are assumed to influence the distribution of bargaining power within the household. Such outcomes include the amount and allocation of leisure time, spending (on women's and children's clothes versus men's clothes, on alcohol and tobacco, on food) and domestic violence (including female suicide rates).

However, none of the recent studies directly show how individual preferences affect households' decisions. In this paper, we analyze data from the HRS reporting whether a husband or wife has "the final say" when making major decisions in a household. We interpret this question as revealing whose preferences are reflected to a greater degree in household decisions. By directly observing decision-making power, our analysis overcomes endogeneity problems arising in many earlier studies and constitutes the missing link that confirms the importance of household bargaining.

To undertake this analysis, we develop an econometric framework and pose a set of identification assumptions to make use of multiple subjective reports. We find that decisionmaking power depends on plausible variables within the household and also influences important household outcomes. Moreover, the second set of results is much stronger than the first set. Current and lifetime earnings have a significant but only moderate influence on decision-making power. On the other hand, decision-making power has important effects on a sample of financial decisions that we examine.

In the first set of results, we analyze determinants of whether the husband or wife has more decision-making power. We find that decision-making power depends significantly on relative household earnings, and more so on average lifetime earnings than on current earnings. However, the magnitudes of these estimated effects are only moderate for this older sample switching average lifetime earnings of husbands and wives reduces the predicted percentage of men reported to have the final say by their wives from $31.1 \%$ to $21.6 \%$. These estimates control for human capital variables that may be correlated with both labor supply and a comparative advantage in making important decisions. They also show that cultural factors like race, religion, and immigrant status affect decision-making power.

Next, we show that we can use this data to investigate outcomes that are both novel in the household bargaining literature and important. As an example, we investigate two financial outcomes that are well-recorded in the HRS. We find that when husbands have greater decisionmaking power, the household invests significantly and substantially more in equities, controlling for important factors like household wealth and stated risk preferences. This confirms evidence found by others that men are less risk averse and shows some practical consequences. We also 
find an intriguing twist on the standard life cycle model. We find that, when husbands have the final say, household wealth is significantly and substantially higher the older is the husband but not the wife, and when wives have the final say, household wealth is higher the older is the wife. Thus, life cycle planning motives may be driven by the interests of the spouse in charge.

Thus, our conclusions are twofold. Our results show that household bargaining can have important effects on the welfare of household members. For example, the relatively high rate of poverty among widows may result not only from aggregate longevity shocks, insurance market failures, and/or poor planning, but also from the nature of household bargaining earlier in life. ${ }^{1}$ This, in turn, has implications for the design of dependent and survivor benefits available through Social Security and for the impact of the shift from annuitized defined benefit pensions to lump-sum defined contribution accounts. Our results also make it clear that more research is needed into the determination of bargaining power, as even important variables like earnings explain relatively little about the distribution of bargaining power.

\section{PAST EVIDENCE ON HOUSEHOLD BARGAINING}

\section{A. Past empirical literature}

While most consumption and wealth data is collected at the household level, many studies have raised doubts that households can be treated as unitary decision makers. ${ }^{2}$ Theoretical work that began with McElroy and Horney (1981) and Manser and Brown (1981) has assumed instead that spouses engage in cooperative bargaining. The resulting Nash-bargained equilibrium allocates marital surplus according to each spouse's bargaining power. Bargaining power depends in turn on spouses' threat points, assumed most often to be their utility from divorce.

While plausible, direct tests of such models are hampered by the unobservability of bargaining, threat points, and the allocation of marital surplus. Consequently, the empirical literature has employed indirect tests of implications of unitary decision-making models. Many of these tests rely on similar identification strategies, which we discuss in the next section, to test the "income pooling" hypothesis. Under unitary models, the distribution of resources within the family should not influence outcomes like expenditures. Empirical papers have shown, to the contrary, that variation which is plausibly influenced by threat points alters household outcomes over which spouses might have different preferences. For example, papers show that the distribution of wages, earnings, or unearned income between spouses affects outcomes like time spent by spouses on leisure and chores (Friedberg and Webb 2005); spending on men's, women's, and children's clothing (Phipps and Burton 1998; Lundberg, Pollak and Wales 1997; Ward-Batts 2003), on alcohol and tobacco (Phipps and Burton; Hoddinot and Haddad 1995; Ward-Batts), and on food (Lundberg, Starz, and Stillman 2003; Duflo and Udry 2004; Ward-Batts); and child outcomes like health and education (Schultz 1990; Thomas 1990, 1994; Haddad and Hoddinott 1994; Rose 1999; Duflo 2003; Duflo and Udry). ${ }^{3}$

\footnotetext{
$118.0 \%$ of widows aged 65 and over lived in poverty in 1997, compared to $13.1 \%$ of all elderly women and $13.3 \%$ of the total population (National Economic Council 1998).

${ }^{2}$ See recent surveys by Bergstrom (1995), Behrman (1995), Bergstrom (1996), and Lundberg and Pollack (1996).

3 In addition, bargaining is an explanation for rejections of standard implications of individual preference axioms using household-level data (McElroy 1981). Examples include negative price elasticities and violations of Slutsky
} 


\section{B. Comparison to our empirical strategy}

Our approach offers three related advantages over recent studies. First, we have actual measures of decision-making power. As we noted above, earlier studies lacked such measures and had to assume that the variables they had access to influenced the distribution of bargaining power and were influenced by it. We do not have to assume any indirect relationships. Thus, our results constitute strong new evidence in favor of household bargaining models and about the specific nature of bargaining.

Second, because we have a measure of bargaining power, we are not constrained as earlier studies were in choosing outcomes to analyze. The studies mentioned in the previous section jointly test not only income pooling but also differences in spouses' preferences over the outcomes being studied. This is the main reason to study spending on men's and women's clothing. ${ }^{4}$ It is less obvious, though, that men and women have different preferences for alcohol and tobacco, food at home versus away, and children's well-being. In contrast, we can directly test which outcomes depend on our measure of bargaining power. While we lack data on many potentially interesting outcomes, and we need to be able to condition on the right set of additional variables just as any other study does, we can examine outcomes like financial behavior which less obviously reflect the preferences of a particular spouse.

Third, many of the variables which earlier studies used to explain the distribution of bargaining power were arguably endogenous. To give an extreme but relevant example, it would be difficult to conclude that omitted factors played no role in explaining a correlation between religion and spending on clothing, unless we can show (as we do later) that religion directly influences bargaining power. Similarly, the earnings variation used in many tests of income pooling is not plausibly separable from the outcomes being explained. If spouses earn more because they work more, that reduces time that is available for home production and may alter spending on clothing, food, children, etc. Variation in unearned income is similarly problematic for reasons described by Lundberg and Pollak (1996). The cleanest evidence, then, comes from quasi-experiments, but those are limited to particular settings and mostly involve poor populations (Lundberg, Pollak, and Wales; Duflo; Duflo and Udry).

\section{DATA}

\section{A. The HRS}

We use data from the Health and Retirement Study (HRS), a longitudinal survey of over 7,600 households with a member aged 50-60 in 1991. The HRS began in 1992 and collected new data every two years. The HRS reports unprecedented detail about household characteristics, labor supply, finances, health, and so on. We use data from the first wave in $1992 .^{5}$

symmetry. Proceeding from that, Browning et al (1994) and Browning and Chiappori (1999) found that testable analogs of non-unitary models that assume Pareto efficient allocations within the household were not rejected.

${ }^{4}$ This statement ignores possible public good aspects of a spouse's clothing choices!

5 The question about decision-making was asked again in 1994, and 2/3 of individuals gave the same answer. After that, it was only asked of new entrants to the HRS, a considerably smaller group. We do not attempt to analyze changes in bargaining power, which would require not only a theory of dynamic bargaining, but also an approach to distinguishing measurement error from true shifts in either bargaining power or reporting bias. 
Each spouse was asked the following question about decision-making power:

"When it comes to making major family decisions, who has the final say-you or your (husband/ wife/ partner)? By 'major family decisions' we mean things like when to retire, where to live, or how much money to spend on a major purchase."

Individuals could answer that they themselves had the final say, that their spouses did, or that the division of responsibility was "about equal". 6

Because the age range in the HRS is limited, the results are not representative of all households. In particular, since they are older and some unhappy marriages will already have ended, the households that we are observing are more harmonious than average. ${ }^{7}$ On the other hand, the greater marital stability of the sample offers an advantage. We can view the observed outcomes as the steady state of a repeated game, and cooperative bargaining is more likely to be sustained than in a one-shot game. ${ }^{8}$

\section{B. The distribution of the "final say" in the sample}

We took the following steps in selecting our sample from the HRS:

- the HRS interviewed 7,607 households in 1992

- we selected couples, yielding a sample of 5,090

- we eliminated couples with no financial information, yielding a sample of 5,036

- we eliminated couples who were cohabiting, yielding a sample of $4,815^{9}$

- we eliminated couples in which at least one spouse did not answer the bargaining question, yielding a final sample of 4,237.

Table 1 shows the distribution of decision making power in our sample, and Table 2 shows other sample statistics. In Table 1, both spouses report that husbands have more bargaining power, on average. When husbands answered the first question above (as shown across the bottom of the upper panel), $30.6 \%$ reported having the final say, $57.6 \%$ said it was about equal, and $11.8 \%$ reported that the wife had the final say. When the $30.6 \%$ of husbands with the final say answered the second question above (as shown in the lower panel), roughly one-quarter reported having a lot more say, and the rest reported having somewhat or a little more say.

\footnotetext{
6 People were asked a follow-up question if they did not answer "about equal": either, "Do you have a lot more say than your (husband/ wife/ partner), somewhat more, or only a little more?", or, vice versa. The answers to this second question did not provide us with significant additional information. In ordered probits, the estimated threshold values are not significantly different from each other when we try to explain answers to the second question, but they are when we try to explain answers to the first question in the estimates we report later.

7 While the value of observed marriages in the HRS should be higher than the value of a representative marriage and thus disagreement should be less likely, this does not have clear-cut implications about the observed distribution of bargaining power relative to the underlying distribution for all couples. We find that controlling for the duration of marriage has no impact on the other coefficient estimates. Interestingly, we find smaller estimated effects of earnings on bargaining power in second marriages, perhaps because people enter a second marriage with more information about the likely distribution of bargaining power.

${ }^{8}$ Because we find significant effects later on, we believe that these answers are informative. Thus, it seems unlikely that one spouse has more power but delegates decision-making to the other spouse, knowing that the decisions will reflect their own preferences.

9 While cohabiting couples have surplus to bargain over, that surplus is expected to be lower on average (Brien, Lillard, and Stern 2004).
} 
The marginal distribution of wives' answers to the first question is similar to husbands'. $16.0 \%$ of wives reporting that they themselves have the final say, $52.7 \%$ answering that it was about equal, and $31.3 \%$ reporting that their husbands have the final say.

Disagreements are apparent in the off-diagonal cells in the upper panel of Table 1. Spouses agreed on the answer $63.3 \%$ of the time. $84.2 \%$ of the disagreements occurred in adjacent cells, while the rest involved one spouse answering the wife and the other answering the husband. About 2/3 of these adjacent disagreements leaned toward the husband, with one spouse attributing more power to the husband and the other reporting equal power. It was also a little more common for disagreeing spouses to attribute extra power to themselves relative to the other spouse's opinion (adding together cells in the lower left) than it was for them to attribute extra power to the other spouse (cells in the upper right).

\section{EMPIRICAL APPROACH}

We interpret answers to the question about decision-making as revealing which spouse's preferences are reflected to a greater degree in household decisions. ${ }^{10}$ However, we treat the answers as noisy measures of true decision-making power, both because the answers are discrete and because of the disagreements revealed in Table 1. Moreover, disagreements are correlated with some of our important explanatory variables in the results we present later.

In this section, we offer an econometric framework that suggests intuitive identification assumptions to disentangle these features. We first present a framework to deal with noisy, continuous measures of bargaining power, and then noisy, discrete measures. While the identification assumptions influence the interpretation of the reported coefficient estimates, they are not actually imposed in the process of estimation, so uninterested readers can proceed directly to the next section for the estimation results.

\section{A. Estimating the determinants of noisy measures of true bargaining power}

We assume for the moment that spouses report continuous (rather than discrete) measures of bargaining power. We will focus first on determining how bargaining power, measured continuously, depends on household characteristics and then how it influences household outcomes. We will denote true bargaining power of a husband relative to his wife in household $i$ by $y_{i}{ }^{*}$. We will treat true bargaining power $y_{i}{ }^{*}$ as a function of observables $X$ and an uncorrelated homoscedastic error term:

$$
y_{i}^{*}=X_{i} \alpha+u_{i}
$$

\footnotetext{
${ }^{10}$ Household theory has emphasized the generalized Nash model of cooperative bargaining, in which the allocation of resources $\left(U_{h}, U_{w}\right)$ maximizes $\left(U_{h}-R_{h}\right)^{\theta}\left(U_{w}-R_{w}\right)^{1-\theta}$, where $U$ is utility in marriage, $R$ is reservation utility, and $0<\theta<1$ is h's relative bargaining weight. The equilibrium allocation $U_{j}$ will depend on $R$ and $\theta$, and we view our measure of decision-making power (which we also refer to on occasion as "bargaining power") as an amalgam of $R_{h}, R_{w}$, and $\theta$. We are not aware of other data with direct measures of any of these variables. In comparison, empirical tests of income pooling seek to determine whether components of $R_{j}$ influence components of $U_{j}$. A natural extension of our work would be to incorporate additional information and estimate the full Nash-bargaining model, as several papers have done in labor market settings (cf. Flinn forthcoming).
} 
We do not observe $y_{i} *$ but rather the belief $y_{j i} *$ about true bargaining power that each spouse $j=$ $\{h, w\}$ in household $i$ reports. We write these beliefs as

$$
\begin{aligned}
& y_{w i} *=y_{i}^{*}+X_{i} \beta_{w}+u_{w i} \\
& y_{h i} *=y_{i}^{*}+X_{i} \beta_{h}+u_{h i},
\end{aligned}
$$

so $j$ 's report about the husband's relative bargaining power depends on his true bargaining power but also on some reporting bias $X_{i} \beta_{j}$ and another uncorrelated homoscedastic error term.

Before proceeding with estimation issues, we will clarify some important identifying assumptions that lie behind (1)-(2b). First, the model assumes that the "true" measure of decision-making power $y_{i}{ }^{*}$, rather than the reported measures $y_{j i}{ }^{*}$, influence household decisions. Otherwise, we might have to consider a model of multi-dimensional bargaining in order to reconcile conflicting reports that are both true. ${ }^{11}$ Second, the model assumes specific forms of heterogeneity in how everyone reports $y_{j i}{ }^{*}$. Answers may disagree or not as a function of observables and error terms, but it assumes that couples whose answers disagree or not do not fundamentally differ in either how they answer the question or how they bargain.

To proceed, we can rewrite each spouse's report of bargaining power in (2a) and (2b) as

$$
\begin{aligned}
& y_{w i} *=X_{i}\left(\alpha+\beta_{w}\right)+u_{i}+u_{w i} \\
& y_{h i} *=X_{i}\left(\alpha+\beta_{h}\right)+u_{i}+u_{h i},
\end{aligned}
$$

but, of course, we can only estimate the empirical analogs

$$
\begin{aligned}
& y_{w i}^{*}=X_{i} b_{w}+\tilde{u}_{w i} \\
& y_{h i} *=X_{i} b_{h}+\tilde{u}_{h i} .
\end{aligned}
$$

Thus, we have an identification problem since $b_{j}=\alpha+\beta_{j}$ combines the "true effect" $\alpha$ of $X$ on $y^{*}$ and the "reporting bias" $\beta_{j}$ also engendered by $X$.

In order to identify the true effect $\alpha$, we propose the following restriction:

$$
\beta_{h}+\beta_{w}=0 .
$$

This condition requires that any disagreements between spouses about true bargaining power be equal and opposite in sign, so that they balance out on average across the sample.

This restriction is an intuitive extension of the assumption that respondents provide unbiased information. As an example, consider our result later that a wife's (W's) earnings reduces her husband's (H's) bargaining power but by amounts that are disagreed on. Suppose that higher W's earnings reduce true $y_{i}$ by an average of 0.5. A symmetric disagreement arises if higher W's earnings lead Ws to claim a greater drop and Hs to claim a smaller drop. If instead they disagreed in the same direction (e.g., Hs and Ws report average reductions of 0.6 and 0.7 , respectively), then we could not identify the true effect on bargaining power (which we would infer lies between 0.6 and 0.7 ) from this systematic reporting bias. Instead, we infer that anything that moves both spouses' reports in the same direction is the truth. Similarly, if the

\footnotetext{
${ }^{11}$ In such a model, spouses might report different answers because they engage in distinct bargaining over different decisions. Such models are theoretically intractable and would be difficult to identify using our data, since we would not know what "sphere" of bargaining each spouse has in mind when answering the question.
} 
disagreement were opposite in direction but not symmetric (e.g., Hs and Ws report average reductions of 0.4 and 0.7 ), then we would correctly infer that the truth lies in between 0.4 and 0.7 , but we would incorrectly infer where. ${ }^{12}$ This assumption makes sense as long as, once again, both spouses interpret the question in the same way, on average. ${ }^{13}$

Once we estimate (3a) and (3b) and then impose (4), we can recover the underlying parameters of interest. Since $b_{h}=\alpha+\beta_{h}$ and $b_{w}=\alpha+\beta_{w}$, it can be shown that

$$
\begin{aligned}
& \alpha=\left(b_{h}+b_{w}\right) / 2 \\
& \beta_{j}=b_{j}-\alpha=b_{j}-\left(b_{h}+b_{w}\right) / 2 .
\end{aligned}
$$

Thus, our estimate of the true effect $\hat{\alpha}$ equals the average of $\hat{b}_{h}$ and $\hat{b}_{w}$, and our estimate of the reporting bias $\hat{\beta}_{j}$ equals $\hat{b}_{j}$ minus $\hat{\alpha}$. In cases where there is little disagreement, $\hat{b}_{w} \approx \hat{b}_{h}$, so $\hat{b}_{j} \approx \hat{\alpha}$ and $\hat{\beta}_{j} \approx 0 .{ }^{14}$ A final issue is whether the errors in the reporting equations (2a)-(2b) and hence the estimating equations (3a)-(3b) are correlated. ${ }^{15}$ We test this hypothesis later on and find a large, positive, statistically significant correlation.

\section{B. Estimating the consequences of noisy measures of true bargaining power}

Using noisy measures of bargaining power also affects how we interpret estimates of the consequences of bargaining power on household outcomes. Suppose some outcome $z_{i}$ depends on true continuous but unobserved bargaining power $y_{i}{ }^{*}$, as defined in (1), and on $X$ (which affect true and reported bargaining power as well) and an uncorrelated homoscedastic error term, so that

$$
z_{i}=\gamma y_{i}^{*}+X_{i} \delta+v_{i}
$$

We can substitute $(2 \mathrm{a})$ and $(2 \mathrm{~b})$ to obtain

$$
z_{i}=\gamma y_{w i} *+X_{i}\left(\delta-\gamma \beta_{w}\right)+v_{i}-\gamma u_{w i}
$$

12 We could generalize (4) by incorporating asymmetric effects of $X$ on disagreement, such that $\beta_{h}+\beta_{w}=\beta$ $\forall\left|\beta_{j}\right| \geq|\beta|$. This allows $\beta_{h}$ and $\beta_{w}$ to differ in magnitude as long as they also differ in sign but does not yield point identification of $\alpha$ and $\beta_{j}$. If we suspected that an element of $X$ had a greater effect on one spouse's reporting bias than on the other's, then $\beta>0$ and we would know that the estimate of $\hat{\alpha}$ was an upper bound on the true $\alpha$. Also, we could determine how large $\beta$ (the asymmetry of disagreement) would have to be in order to undermine inference about the true sign of $\alpha$.

13 The HRS reported whether the other spouse was present and intervened much during an individual's interview. We find that wives are much more likely to be present for their husband's interviews, and that a spouse's presence is not systematically related to reported bargaining power. The theoretical implication is ambiguous - a spouse with more bargaining power may directly exercise control over the less powerful spouse's answers or may be confident of indirect control that makes intervention unnecessary. When we try controlling for the presence of the other spouse in the estimation, there is little qualitative impact on the estimated effect of earnings, which is our primary interest. It alters the estimated effect of some demographic and cultural variables (i.e., race, religion, children).

${ }^{14}$ In this framework, we cannot identify the true effect $\alpha$ by limiting the sample to couples who report the same answers for $y$. It is not the case that such couples have no reporting bias, but rather that their reporting errors $u_{j i}$ happen to offset their reporting bias $X_{i} \beta_{j}$, that they have systematically lower values of variables associated with high reporting bias and vice versa, etc. With that in mind, we will mention the effect of limiting the sample when we present the estimation results later.

15 We cannot identify a correlation between the disturbance in the true equation (1) and the reporting equations (2a)(2b) without making a further assumption, analogous to (4), about the nature of the correlation. 


$$
z_{i}=\gamma y_{h i} *+X_{i}\left(\delta-\gamma \beta_{h}\right)+v_{i}-\gamma u_{h i}
$$

and then add these together to arrive at

$$
\left.z_{i}=\chi \frac{y_{h i}^{*}+y_{w i}^{*}}{2}\right)+X_{i}\left(\delta-\frac{\gamma}{2}\left(\beta_{w}+\beta_{h}\right)\right)+v_{i}-\frac{\gamma}{2}\left(u_{w i}+u_{h i}\right) .
$$

The empirical analog of (7) is

$$
z_{i}=c\left(\frac{y_{h i}^{*}+y_{w i}^{*}}{2}\right)+X_{i} d+\tilde{v} .
$$

If we estimate (8) and invoke the assumption in (4) that $\beta_{h}+\beta_{w}=0$, then we can recover the true parameters from (6), which are simply $\gamma=c$ and $\delta=d$ The key point is that averaging $y_{h i}{ }^{*}$ and $y_{w i} *$ in the estimation cancels out the disagreement effects $\beta_{j}$.

\section{Estimating the causes and consequences of discrete measures of bargaining power}

At this point, we will address the fact that our observed reports of bargaining power are discrete rather than continuous. In order to estimate the determinants of bargaining power, we continue to assume that (1)-(2b) hold, with $y_{j i}{ }^{*}$ now being some underlying continuous measure that we only observe discretely:

(9) $y_{j i}=\{$ husband has final say, about equal, wife has final say $\}=\{1,0,-1\}$

Assuming further that $\tilde{u}_{j i} \sim N\left(0, \sigma^{2}\right)$ yields an ordered probit framework that is the discrete choice analog to (3a) and ( $3 b$ ), where the contribution of each possible outcome of $y_{j i}$ to the $\log$ likelihood function is

$$
\begin{aligned}
& P\left(y_{j i}=-1\right)=\Phi\left(\mu_{0}-X_{i} b_{j}\right) \\
& P\left(y_{j i}=0\right)=\Phi\left(\mu_{1}-X_{i} b_{j}\right)-\Phi\left(\mu_{0}-X_{i} b_{j}\right) \\
& P\left(y_{j i}=1\right)=1-\Phi\left(\mu_{1}-X_{i} b_{j}\right),
\end{aligned}
$$

and $\mu_{0}$ and $\mu_{1}$ are threshold values to be estimated. Since the relationship $b_{j}=\alpha+\beta_{j}$ continues to hold, then, after imposing (4), the same conditions (5a) and (5b) govern identification. Lastly, we will estimate a bivariate ordered probit that allows the errors $\tilde{u}_{j i}$ to be correlated for spouses $j$ within a household $i$. Such a correlation may be expected if spouses share important characteristics that influence both bargaining and reports about bargaining and that are not observed in the data.

When we consider estimating the consequences of our noisy, discrete measure of bargaining power, the estimation strategy outlined in (8) becomes more complicated since we do not observe the continuous variables $y_{j i}{ }^{*}$. We can deal with this in one of three ways. One alternative is a two-stage procedure in which we estimate the ordered probits that determine bargaining power in the first stage, predict values of $\hat{y}_{j i} *=X_{i} \hat{b}_{j}$, substitute those into (8) and estimate the impact of bargaining power in the second stage. The difficulty with this approach is in determining how to adjust the standard errors in (8). ${ }^{16}$ Another alternative is to, first, estimate

\footnotetext{
16 Maddala (1983, Section 8.8) lays out estimators and, in some cases, covariance matrices for related examples in which the first and/or second stages are specified discretely. None pertain directly to the situation here, and for the
} 
the reduced form obtained from substituting the determinants of $y_{j i}{ }^{*}$, as laid out in (3a) and (3b), directly into (8) and then, second, obtain the structural parameters from (6) based on the resulting restrictions. This approach is based on Amemiya (1979) and is described in the Appendix. We report results from both approaches but prefer the second because it is more efficient and does not require complicated adjustments to the standard errors. A third approach, which we will not use, would be a joint estimation strategy that allows the error terms determining $y_{h i}{ }^{*}, y_{w i}{ }^{*}$, and $z_{i}$ to be correlated. This approach would get rapidly more complicated as we analyze additional outcomes $z$, though, so we limit the joint estimation to $y_{h i}{ }^{*}$ and $y_{w i}{ }^{*}$.

Using either of the first two approaches, we now face an additional constraint because $\hat{y}_{j i} *$ is a linear function of the explanatory variables $X$ which also appear linearly in (8). Therefore, we must exclude one or more elements of $X$ so that we can identify the impact $\gamma$ of $y_{i}{ }^{*}$ on $z .{ }^{17}$ To this end, we will argue that total household earnings should affect outcomes $z$ that we analyze, but that the split between husband's and wife's earnings should not, except through their influence on bargaining power.

\section{WHAT INFLUENCES BARGAINING POWER?}

In this section, we analyze the empirical determinants of decision-making power. We estimate bivariate ordered probits on both spouses' answers $y_{j i}$ about decision-making power, coded as $\{1,0,-1\}=\{$ husband has final say, about equal, wife has final say $\}$. We hypothesize that labor market opportunities of each spouse affects threat points and in turn bargaining power. To test this, we explore the impact of current and past earnings and other labor market variables. ${ }^{18}$

The HRS offers a great deal of information to control for other factors that may affect both threat points and decision making. For example, a spouse who is "savvier" than the other may be more likely to work and make major decisions, inducing a spurious correlation. To deal with this, we control for each spouse's human capital as reflected by education, cognition, and health. ${ }^{19}$ Cultural background and social norms may be correlated with both threat points and decisionmaking power, so we control for numerous background variables - race, hispanic ethnicity, immigrant status, religious background, and father and mother's education. We find that many

most similar cases, he notes, "The derivation of the asymptotic covariance matrix of the two-stage estimates is very complicated and will not be attempted here," (pp.245, 246). We do not attempt it either.

17 If we observed the continuous values $y_{j i}{ }^{*}$, then the variation in reported bargaining power that is uncorrelated with $X$ would identify the impact of $y^{*}$ on $z$.

18 Pollak (2005) laid out the case that the wage, rather than earnings, is the appropriate proxy for the bargaining threat point, as hours of work may differ across bargaining equilibria. Measuring the marginal wage accurately for this age group proved difficult, though, as salaried jobs are the norm. Moreover, total earnings might better proxy the threat point in this case, since hours adjustments are difficult at this age; for example, a non-working spouse may find it difficult at this age to exercise what earlier was a legitimate threat to earn a high wage by returning to work.

${ }^{19}$ We use two of three measures of cognition reported in the HRS. The first, V5105, began, "Next, I'll read a set of 20 words and ask you to recall as many as you can. We have purposely made the list long so that it will be difficult for anyone to recall all the words - most people recall just a few." We use the number that was answered correctly. We also used V5113, which adds together the number of fully or partially correct answers to a series of seven questions from the Wechsler Adult Intelligence Scale. We did not use a third variable, V5126, which had little explanatory power in our estimates. For missing observations on cognition, we used hot-deck imputation with income and education as explanatory variables. 
of these variables have statistically significant effects on decision-making power, although ethnic variables also have the strongest effects on disagreements.

\section{A. The impact of husband's and wife's earnings}

We show estimation results for various specifications of labor market variables (including current earnings, earnings histories, and others) in bivariate ordered probits estimated jointly on both spouses' responses. Throughout these specifications, we obtain a positive, significant correlation coefficient of around $0.45 .^{20}$ Thus, conditioning on observables, both spouses agree about who has decision-making power on average, but not perfectly.

After reviewing various specifications, we will decompose the parameter estimates from some preferred specifications into the "true" and the "disagreement" or "bias" effects that result from imposing (4). Then, we will discuss the magnitude of the estimated effects on the distribution of decision-making power. In the meantime, recall that the estimated effect $\hat{\alpha}$ of a variable on true decision-making power equals the average of its estimated effects $\hat{b}_{h}$ and $\hat{b}_{w}$ on husbands' and wives' reports, which we discuss next. Also, the importance of any particular variable can be gauged by comparing its coefficient to the estimated threshold values $\hat{\mu}_{0}$ and $\hat{\mu}_{1}$, based on (10).

Current earnings (Table 3-A). We generally find that earnings have a significant effect on decision-making power. In our first set of results, a wife's current annual earnings significantly lower both spouses' reports of the husband's decision-making power (with the impact on her husband's and her own report shown in columns (1) and (2), respectively). A husband's earnings also significantly raise his wife's report of his decision-making power. Interestingly, a wife's earnings matter several times more than a husband's in explaining both reports, while earnings of both spouses affect the wife's report by about twice as much as the husband's. ${ }^{21}$

We can also attribute pension income to each spouse. Though the estimates are not statistically significant, each spouse's pension income from earlier jobs and pension participation in a current job affect reported decision-making power with the same signs as earnings in almost all cases. Once again a wife's pension has a much greater effect than a husband's.

Earnings histories (Table 3-B). The HRS provides restricted information about earnings histories reported by the Social Security Administration for 1951 to 1991 . We computed the average annualized present value of past annual earnings over this period and substituted it in place of current earnings on the right-hand side. We have this data for $77 \%$ of the couples in our original estimation sample. $^{22}$

\footnotetext{
20 This exceeds the raw correlation coefficient of 0.36 . We used univariate coefficient estimates as starting values, and they consistently yielded a higher log likelihood than did many alternatives that we tried. Most parameter estimates, including those on earnings, were very similar across the univariate and bivariate specifications.

${ }^{21}$ If we limit the sample only to couples whose reports agree (which involves a different set of identifying assumptions, as we mentioned earlier), then the estimated earnings coefficients rise by about $1 / 3$. The biggest gains in parameter estimates occur in those categories - race, ethnicity, national origin - that cause the most disagreement.

22 We do not have data for respondents who refused to provide their Social Security number or who provided a number that could not be matched. We imputed earnings that were topcoded at the Social Security payroll tax limit. If we run the earlier specifications from Table 3-A on the limited sample from Table 3-B, the estimated effects of current earnings are very similar.
} 
We find that average past earnings in column (2) have a substantially greater impact on decisionmaking power than current earnings in (1) do. The estimated effect of husbands' earnings roughly doubles, though it is statistically insignificant, while the effect of wives' earnings triples and is highly significant. In column (3), we seek to distinguish the effect of current earnings and a measure of human capital, as indicated by average earnings over the ages of 22-45. In this specification, wives' current and average earnings affect her report, while wives' current earnings affects his report.

Other human capital variables (Table 3-A). There are two ways that skill- and work-related variables might affect decision-making power. First, they may capture information about threat points that is not reflected in current earnings, in which case we should consider the effects of these variables alongside that of earnings. Second, these variables may reflect other characteristics about the individual which are related to decision-making - for example, assertiveness, that is also associated with self-employment. In that case, it would be important to control for them in order to isolate the effect of earnings.

In fact, in later specifications that omit work-related variables, we find very little change in the earnings estimates, so neither possibility seems like a major concern. In the specification in Table 3-A, we find that the effect of skill on bargaining power, as measured by occupation and education, is sometimes statistically significant and generally monotonic, raising own and reducing a spouse's decision-making power. The differential effect of being in the highest versus the lowest skilled occupation is similar in magnitude to the differential effect of having attended college versus not having completed high school.

Being self-employed also has strong effects on one's reported decision-making power. If the husband is self-employed, it raises his reported power by over one-third more than the difference between low and high skill does. It raises his wife's report of his power, but by less. A wife's self-employment reduces the husband's power, but the effects are considerably smaller. Lastly, other human capital variables - cognition, health, parents' education - have minor effects on bargaining power.

Additional labor market variables (Table 3-C). We explored additional specifications with different combinations of earnings and other work variables. These estimates reinforce our results about the impact of earnings on bargaining power.

By including controls for weekly hours of work in column (1), the coefficients on earnings can be thought of as isolating the effect of wages on decision-making power. ${ }^{23}$ The estimated effects of a wife's labor market activities are now split between hours of work and earnings (which represents wages, when controlling for hours), and both are statistically significant. Finding an effect of hours of work indicates that wives may "exercise" their threat to some extent by working, which raises their decision-making power.

As we mentioned earlier, it is difficult to know how to interpret the occupation and selfemployment variables in the main specification - they may help measure threat points or they may capture omitted characteristics correlated with decision-making power. Thus, it is

\footnotetext{
23 As we noted earlier, measuring the marginal wage accurately for this age group is difficult, as salaried jobs are
} the norm. 
interesting to note that including simple work dummies in (2) instead of occupation and selfemployment had little effect on the earnings estimates. If we, instead, exclude all other human capital and cultural variables and control only for work-related variables in (3), the estimated effects of earnings are a little smaller. This reduces concerns that wives' earnings are correlated with cultural variables in ways that undermines conclusions about the effect of earnings.

The last two specifications use transformations of the earnings variables, since we do not know exactly how earnings affect threat points. Including the log instead of level of earnings in (4) yields estimated magnitudes of the effects of earnings that are similar. The specification in (5) indicates that relative as well as absolute earnings influence threat points. The ratio of earnings is now significant, while the level of earnings remains statistically significant for the wife's reported power. These results show that shifting a wife from having $25 \%$ to $75 \%$ of total earnings reduces husband's reported bargaining power by as much as increasing the wife's earnings by $\$ 25,000$.

\section{B. Understanding the estimated effect of earnings}

In this subsection, we discuss the magnitude of the estimated impact of earnings and other work variables. First, in Table 4 we present estimates and standard errors (based on the delta method) of the true effects of all of the covariates on decision-making power, as well as the reporting bias induced by each covariates, based on our identifying assumption in (4).

In Table 3-A, the estimated coefficient of wives' current earnings/10,000 was $-0.0356(0.0149)$ for husbands' reports and $-0.0753(0.0149)$ for wives' reports. The resulting estimate of the true effect is the average, $-0.0555(0.0126)$, while the reporting bias is $0.0198(0.0160)$ on husbands' reports (and -0.0198 on wives' reports). Similarly, the true effect of wives' average past earnings (at the bottom of Table 4) is -0.01756 (0.0337) and the reporting bias on husbands' reports is $0.0650(0.0570)$.

Next, we analyze the magnitude of these estimated effects in Table 5. We do this by simulating the effect on the distribution of decision-making power of altering husbands' and wives' earnings and work status. We compare the results to a set of baseline predictions that use the estimated coefficients together with everyone's actual earnings, and another set that assigns average earnings by gender to parallel the simulations. Because the interpretation of the occupation and self-employment variables is ambiguous - it is unclear whether they reflect threat points or individual characteristics - we use similar estimates in which a simple work dummy substitutes for occupation and self-employment (as in column (2) of Table 3-C). ${ }^{24}$

For example, if we switch average current earnings of men and women, then the predicted percentage of husbands having the final say falls from 31.0 to $28.2 \%$, according to husbands' reports, and from 32.3 to $26.6 \%$, according to wives' reports. ${ }^{25}$ If we do the same but switch average past earnings, then the declines are double in magnitude - from $31.5 \%$ to $19.7 \%$, according to wives' reports. If we compare all husbands and no wives working to all wives and no husbands working (with the working spouse earning the conditional average by gender), then

${ }^{24}$ In Table 5 we use the estimated coefficients rather than the estimated "true effects" to give a complete sense of the data that does not rely on our identification assumption. If we used the estimated true effects, the predictions would lie approximately in the middle of those based on the husbands' and on the wives' answers.

25 Average earnings of husbands and wives in our sample are \$38,348 and \$11,897, including nonworkers. 
the percentage of husbands having the final say, as reported by wives, swings from $37.5 \%$ to $27.3 \%$, and the percentage of wives having the final say rises from $11.5 \%$ to $18.0 \%$.

Overall, we characterize these effects as moderate. They show a clear, but not large, effect of earnings on bargaining power that should be kept in mind when considering tests of income pooling that are common in the literature. Moreover, further research may shed light on the extent to which bargaining in the HRS cohort may differ from later cohorts that have experienced major changes in divorce rates, fertility, women's labor supply and earnings, etc.

\section{The impact of other control variables}

We included a large set of variables reflecting ethnic and cultural background. Coefficient estimates appear in Table 3-A, and the decomposition into true effects and reporting bias appear in Table 4. Some of these have significant effects on bargaining power, which is interesting for three reasons. First, these background factors may be correlated with the labor supply of each spouse. Second, cultural factors may affect threat points. For example, cultural norms may influence the willingness of a spouse to consider divorce by reducing utility outside of marriage. Alternatively, they may reflect the degree to which the community favors one spouse over the other in the event of conflict. Third, some of the background variables lead to considerable disagreement between the spouses' reports about decision-making power.

Race, national origin, and ethnicity have some significant effects on reported decision-making power in Table 3-A in roughly descending order in terms of magnitude, although the significance of the true effects is reduced in Table 4. If both spouses are black, it has little net effect on the husband's report of decision-making power, while reducing the wife's report of the husband's power. Similar results, though somewhat smaller are found for foreign born couples. ${ }^{26}$

Religion also has strong effects on reported decision-making power, and with much less disagreement. In Protestant and especially fundamentalist or evangelical Protestant couples husbands have significantly more decision-making power. In Catholic and non-religious couples the effects are the reverse, though smaller, while couples reporting different religions have a significant disagreement. ${ }^{27}$ Moreover, regular church attendance by either spouse significantly raises husbands' decision-making power.

It is interesting to find that having kids, especially if they are under the age of 18 , reduces a husband's reported bargaining power considerably. ${ }^{28}$ While it has much less influence on wives' reports in the main specification, both effects are greater in specification 3-B (2) with average past, rather than current, earnings. The true effect of having children under the age of 18 in this specification is negative and statistically significant at the $90 \%$ confidence level.

\footnotetext{
26 As these variables generate considerable disagreement, we find substantial increases in their coefficient estimates if we limit the sample only to couples whose reports agree.

27 We define religious differences based on these broad categories, which are aggregated over many denominations.

28 In theory, kids might shift bargaining power in either direction (increasing the wife's power if she has disproportionate influence over kids' emotional well-being or increasing the husband's if he has disproportionate influence over their material well-being). We cannot explain why perceptions about the impact of kids might differ across spouses.
} 
In addition, increased age of both spouses (or else cohort effects) reduces a husband's reported bargaining power a little. Lastly, we find little effect of controls for information about individuals' time horizon and risk preferences, which we include because they shape some of the household decisions which we investigate later.

\section{WHAT DOES BARGAINING POWER INFLUENCE?}

In this section, we demonstrate that decision-making power influences important household decisions. As examples, we focus on two financial outcomes that are well-measured in the HRS: total wealth accumulation and stock market investment. Both sets of estimated effects are important in magnitude, though somewhat sensitive to the specification.

Our findings about wealth accumulation diverge in an interesting way from standard life cycle predictions: household assets rise with the husband's age when husbands are in charge and with the wife's age when wives are in charge. Thus, it appears that the spouse with the final say may be making decisions based primarily on their own life-cycle prospects. We show that this difference is only partly explained by our other main result: when husbands are in charge, the household take on more risk by investing more of the household portfolio in equities. While we do not elaborate on underlying life cycle models that may be associated with these patterns, they suggest important directions for future research.

\section{A. Estimation approach}

We use three methods to estimate the impact of bargaining power. We maintain the assumption throughout that total earnings in the household may be related to these financial outcomes, but the split between spouses' earnings is not, except through its influence on bargaining power. ${ }^{29}$ As we noted earlier, this is necessary in the structural models because we do not observe continuously measured bargaining power but instead use variables that influence bargaining power to, in effect, impute a continuous measure. ${ }^{30}$ Besides that, we include all non-income related control variables used earlier to explain decision-making power, and we add self-reported information on each spouse's life expectancy, which influences their time horizons.

The first two methods that we use yield structural estimates of equation (6), relating the impact of decision-making power $\gamma$ to an outcome $z$. We will highlight the more efficient approach, described in the Appendix and based on Amemiya (1979), which uses reduced form and firststage estimates to obtain the structural parameters of the second stage. We compare that to a standard two-stage approach that substitutes into (6) an estimate of $\hat{\gamma}$ obtained from our earlier

\footnotetext{
29 While earnings and other work-related variables may be endogenous, they are typically included in financial regressions and play a major role in explaining the observed variation (Miniaci and Weber 2002). One motivation is that, while wealth and portfolio allocations vary substantially by income, they also vary substantially within income groups, and it is this variation that the other control variables seek to explain. This approach also addresses concerns that omitting earnings might bias the estimated effect of predicted bargaining power. In any case, excluding income and work-related variables typically has little impact on the estimated effect of bargaining power.

${ }^{30}$ We were interested in analyzing life insurance holdings as well because of the potential link between bargaining power during marriage and the poverty of widows, but the exclusion restriction was unreasonable in that case since the decision to insure a spouse's life should depend directly on that spouse's earnings. Another difficulty is that the HRS does not report whose life is insured, but rather which spouse owns the policies.
} 
specifications. Here, we can control for the log rather than level of total household earnings, but the estimates are less efficient and have incorrect standard errors. Controlling for the log of income is preferred on a priori grounds (especially when utility is CRRA) and is typical in regressions involving financial behavior. Typically, the estimated effect of decision-making power loses some explanatory power under the efficient estimation approach but remains statistically significant.

With either structural method, the results are somewhat sensitive to the choice of which firststage estimates to use. We try the specifications with current earnings (from Table 3-A), average past earnings (Table 3-B 2, for a smaller sample), and the ratio of earnings (Table 3-C 5). When we use the last specification, we can control for the log rather than level of total household earnings in the first estimation approach for reasons that are detailed in the Appendix.

Lastly, we find similar effects of decision-making power in our third approach, which is a nonstructural alternative to (6) that controls for the discrete answers about decision-making power. This approach does not rely on the functional form represented by (1)-(2b) that we assumed in the first stage, but it revives the original difficulty of extracting information from the discrete and sometimes conflicting answers of spouses. On the other hand, it allows us to control for the log rather than level of household earnings and even to include spouses' earnings separately, which has little effect on the estimated results.

\section{B. Wealth and age}

Background. As long as households expect to retire at some point, then life cycle models predict that wealth will rise with age until retirement. Moreover, households appear to do most of their life cycle saving in their 40s and 50s (Gourinchas and Parker 2002), which coincides well with the HRS. However, bargaining within the household may be particularly salient here since husbands, with shorter lifespans and younger wives on average, should have shorter time horizons than their wives (Browning 2000). Wives should prefer to accumulate more life cycle saving than husbands, yet widows have higher poverty rates than the population average.

Our results about the role of bargaining power can help resolve this puzzle. We find that, when men are in charge, households with older husbands have significantly higher wealth and households with older wives have significantly lower wealth; and when wives are in charge, the results are reversed. Thus, it appears that the spouse with the final say makes decisions based on their own life-cycle prospects.

We regressed log household wealth on decision-making power and interacted it with each spouse's age, and also included total household earnings, other controls used in our earlier regressions, and the subjective life expectancy of each spouse. We show a small subset of coefficient estimates in Table 6, the key ones being the interaction of decision-making power with each spouse's age. The top panel shows the efficient estimation approach, the middle panel shows the standard two-stage approach, and the bottom panel shows the non-structural approach with the raw answers on decision-making power.

It is worth noting at the outset that the coefficients estimated for the main age effects are quite similar in size to those estimated for the decision-making/age interactions. The age coefficients 
generally range between 0.02 and 0.04 , indicating an annual percentage increase in wealth of 2$4 \%$ as each spouse ages.

The additional impact on wealth of the decision-making/age interactions depends on the magnitude of the decision-making power variable. For this purpose, consider the estimated threshold values $\hat{\mu}_{0}$ and $\hat{\mu}_{1}$ reported in Table 3-A. They indicate the values at which the latent continuous variable $\gamma$ is predicted to shift, first, from the wife having the final say to power being about equal and, next, from being about equal to the husband having the final say. The estimated difference between these values - typically about 1.7 - crosses the full range over which decision-making power is "about equal", and we will use that to gauge the magnitude of the effects in which we are interested.

Two-stage estimation. As a baseline, the middle panel of Table 6 reports the two-stage estimates from each of three different first-stage specifications, with incorrect standard errors but with the $\log$ rather than level of household earnings as a covariate. The estimated effects of decisionmaking power when it is interacted with each spouse's age is stable across the three sets of results, taking values around 0.045 for the husband's age and -0.040 for the wife's age.

Efficient estimation. When we use the efficient estimation approach in the top panel, the bargaining power-age interaction effects are smaller. We will focus on the specification with the first-stage estimates that use the ratio of earnings, which worked well in Table 3-C 5 and allows us to control for the log of earnings; and we focus on the log of average past earnings, since it explains more of the variation in wealth than do current earnings. The resulting pair of estimated coefficients on the bargaining power-age interaction lies in the middle of the range in this set of results, at 0.0253 for the husbands' age and -0.0319 for the wife's age. The first coefficient falls just short of $90 \%$ significance and the second coefficient exceeds $95 \%$ significance.

Now, we will consider the implications of these estimates. Recall that if decision-making power shifts from the threshold of the wife to the husband having the final say, then the latent continuous variable $\gamma$ changes by about 1.7 . If such a shift occurs, then household wealth will be $4.20 \%$ higher (the estimated coefficient 0.0253 times the estimated difference in threshold values 1.6593) than it would have been otherwise for each year that the husband is older. Additionally, with such a shift in decision-making power towards the husband, wealth is $5.29 \%$ lower $(-0.0319 * 1.6593)$ for each year that the wife is older. If the reverse takes place, with the household shifting from the threshold of the husband to the wife having the final say, then the effects are reversed: wealth is $5.29 \%$ higher for each year that the wife is older and $4.20 \%$ lower for each year that the husband is older.

To understand the nature of this cross-sectional comparative static, consider a household in which decision-making power is split equally (taking a value of zero). Wealth will be about the same whether the husband is 65 and the wife is 55, or the ages are reversed and the wife is 65 and the husband is 55. That does not hold when decision-making power is unequal. When the husband just barely has the final say, then the first household (husband 65, wife 55) will have accumulated $50.8 \%$ more wealth $\left(1.0420^{10}-1\right)$ than it would have if the wife just barely had the final say. Moreover, the second household (wife 65, husband 55) will have accumulated $67.5 \%$ less wealth $\left(1.0529^{10}-1\right)$ than if the wife had the final say. 
Non-structural estimation. Table 6 also shows alternative estimates that include the raw responses about decision-making power as dummy variables. The age-related patterns are similar, while highlighting the difficulties in interpretation of moving away from the framework laid out in Section III.

When husbands report that they have the final say, household wealth is $4.07 \%$ higher for each year that the husband is older and $3.00 \%$ lower for each year that the wife is older, compared to when husbands report that wives have the final say. These results are statistically significant. When husbands report "about equal", the results are significantly smaller, at $3.18 \%$ higher and $1.39 \%$ lower, respectively, and the first result is statistically significant. The values are similar when we use wives' instead of husbands' reports. Lastly, in estimates that are not shown, we do not reject equality of the coefficients on each spouse's earnings included separately, and doing so has little effect on the other results.

\section{The riskiness of the household portfolio.}

Background. Men in the HRS report somewhat greater risk tolerance than women (Barsky et al 1997). Moreover, other research suggests that men are willing to take on more risk, with single men investing a greater share of their wealth in the stock market than single women (Jianakoplos and Bernasek 1996), men purchasing auto insurance policies that provide less coverage (Cohen and Einav 2004) and men even taking more risks in mundane choices involving seat belt use and preventative dental care (Hersch 1996).

Results in Table 7 reveal the impact of these apparent differences in risk preferences on some important household decisions. We find that, as husbands' power rises, households invest more in the stock market, and this effect is significant in many of the specifications. We estimated probits on whether households invest in the stock market at all (which $32 \%$ in our sample do) and tobits on the share of financial assets invested in the stock market (which is $17 \%$ on average). ${ }^{31}$ As in the previous section, we controlled for total household earnings, other controls used in our earlier regressions, and subjective life expectancy. The coefficient of interest is the one on the decision-making power and "final say" variables.

Two-stage estimation. As a baseline, the middle panel of Table 7 reports estimates from the two-stage approach with incorrect standard errors, but with the log rather than level of household earnings as a control. When we use the current earnings specification from 3-A in the first stage, the marginal effect of the husband's predicted bargaining power on stock market participation in the probit is 0.1811 , and the effect on the desired share of financial assets invested in the stock market in the tobit is 0.2755 . The estimated effects are reduced by about one-third when we use the average past earnings specification from 3-B 2 in the first-stage and increased by about one-

\footnotetext{
31 A caveat is that the HRS does not report the investment allocation of Individual Retirement Accounts or of those defined contribution pensions (including 401(k) plans) that do not offer an investment choice. $45 \%$ of our sample have IRAs, which we omit entirely from the analysis. $35 \%$ have defined contribution pensions, $60 \%$ of which can be identified as offering investment choices; for the latter, the HRS reports whether the account was invested mostly in stocks, mostly in bonds, or "split". This information is vague, though, and we chose to focus entirely on financial wealth and did not consider any form pension wealth. These omissions may lead us to underestimate the effect of bargaining power. For people in our sample whose pensions offer an investment choice, men are significantly more likely than women to invest theirs "mostly or all" in stock.
} 
third when we use the ratio of earnings specification from 3-C 5, whether controlling for the log of current or average past earnings.

Efficient estimation. When we use the efficient estimation approach in the top panel, the estimated effect is smaller for the specifications that control for current earnings (3-A and the first 3-C 5 result) and considerably larger for the specifications that control for average past earnings (3-B 2 and the second 3-C 5 result). Since it is preferable, once again, to control for the $\log$ of average past earnings, we will focus on the last specification - though it should be kept in mind that the resulting estimates lie at the high end of the range.

In the preferred specification, the estimated marginal effect of a small change in decision-making power is 0.4262 for the probit, and the estimated coefficient is 0.6874 for the tobit, both of which are highly significant. If decision-making power in a household shifts, as before, from the threshold of the wife having the final say to the husband having the final say, then the probability that the household invests in the stock market rises by a very substantial 50.9 percentage points. The same shift in decision-making power raises the predicted share of financial assets invested in the stock market by 26.0 percentage points. ${ }^{32}$ By way of comparison, the estimates for the same first-stage specification but controlling for log current earnings are considerably smaller, at 0.2002 for the probit (statistically significant at a little more than $90 \%$ ) and 0.3182 for the tobit (statistically significant at a little less than 90\%). These estimates imply predicted increases of 29.3 and 13.7 percentage points if decision-making power shifts from the wife to the husband.

Non-structural estimation. In the final panel of Table 6, the results are similar when the raw answers are included as dummy variables. If the husband reports having the final say, then the household is $5.1 \%$ more likely to invest in the stock market relative to the wife having the final say and a little greater than that relative to "about equal". The effects are somewhat reduced and not statistically significant based on the wife's reports. As we noted earlier, this specification raises difficulties in reconciling the discrete and sometimes conflicting answers of both spouses.

Lastly, we find some suggestive evidence that other preferences of the individual in charge matter more as well. In results that are not shown, when husbands have the final say, then the household invests more in the stock market if the husband is less risk averse, while wives' risk aversion has no affect. When wives are in charge, wives' risk aversion has substantial effects, though they are not statistically significant. We find similar patterns for time preference.

Summary. Taking our two major sets of results together, we note that the difference in portfolio allocations can explain part but not all of the age-related results. In the benchmark calculation discussed above, a shift from the threshold of the wife to the husband having the final say would raise the predicted share of financial assets invested in the stock market by 26.0 percentage points. According to some simple calculations, this could raise wealth at age 65 by $36.1 \%{ }^{33}$

${ }^{32}$ For the probit, we calculated this as $\Phi\left(\hat{\gamma}_{1}+\bar{X} \hat{\delta}\right)-\Phi\left(\hat{\gamma} \hat{\mu}_{0}+\bar{X} \hat{\delta}\right)$, where notation is based on equations (6) and (10) and $\mu_{j}$ refers to the $j^{\text {th }}$ threshold in the first-stage ordered probit. For the tobit, we calculated the change in the expected censored value of the left-hand side variable using the formula from Greene (2000).

${ }^{33}$ In these calculations, we assume that bonds and stocks earn real returns of $2.25 \%$ and $7.10 \%$, the respective averages for the period 1926-2004. We further assume that people have the lifetime age-earnings profile of the median HRS individual, excluding those with non-zero earnings; that they save a constant fraction of their salary each year from age 22 until they retire at age 65 ; and that they rebalance their portfolio annually. 
Since our earlier benchmark suggested that the same household would accumulate $50.8 \%$ more if the husband had the final say and $67.5 \%$ less wealth if the wife had the final say (both in comparison to decision-making power being exactly equal), the difference in portfolio choices explains only a fraction of the difference in wealth.

\section{CONCLUSIONS}

Our analysis takes advantage of unique data on the distribution of decision-making power between spouses. We interpret this question as revealing whose preferences are reflected to a greater degree in household decisions. We find that decision-making power depends on plausible variables like earnings and also influences some important household outcomes. Moreover, the second set of results is much stronger than the first set.

In terms of outcomes of bargaining, we find that, household wealth is significantly higher the older is the husband but not the wife when husbands have the final say, and the older is the wife but not the husband when wives have the final say - an intriguing twist on the life cycle model. We find further that, when husbands have the final say, households invest significantly more in the stock market, though the difference in portfolio allocations can explain only part of the agerelated results. Being able to investigate outcomes that are both novel in the household bargaining literature and important is a major contribution of our research.

From a policy perspective, the results suggest that household bargaining can help explain the relatively high rate of poverty among widows. This finding, in turn, has implications for the design of dependent and survivor benefits in Social Security. For example, it provides some support for proposals to increase Social Security survivor benefits, especially in case of Social Security personal accounts. With respect to employer-provided pensions, the major structural shift over the last twenty years from annuitized defined benefits towards lump-sum defined contribution accounts may undermine the well-being of widows.

In terms of determinants of bargaining power, our major result in this paper is somewhat negative, since we remain unable to explain a great deal about the observed distribution of bargaining power. Labor market earnings have significant but moderate effects in our estimation results for this older sample - switching average lifetime earnings of husbands and wives reduces the predicted percentage of men reported to have the final say by their wives from $31.5 \%$ to $19.7 \%$. These results are noteworthy because the HRS affords much more detail about the entire path of earnings than data used in previous "income pooling" tests, yet earnings appear to play a limited role in determining threat points.

Thus, future research may focus greater attention to the role of marriage markets, especially since remarriage has become common as divorce rates have risen over time. In addition, it should be possible to extend this research by estimating formal models of bargaining with the HRS data and by exploiting the entry in subsequent waves of the HRS of younger cohorts who were asked the same questions about who has the final say. 


\section{APPENDIX}

We now describe the method that we use to estimate the parameters in (6) when we observe discrete measures $y$ and possibly $z$ rather than the true values $y^{*}$ and $z^{*}$. This approach is based on Amemiya (1979) and was elaborated by Maddala (1983, Section 8.9). Although focusing on the simultaneous tobit model, Amemiya (p.175) noted that, "The principles on which our estimators are based can be applied in general whenever structural parameters need to be determined from the estimates of reduced-form parameters."

While we continue to assume the relationship outlined in (1), (2a), (2b), and (6), the details of separately identifying the parameters $\alpha, \beta_{h}$, and $\beta_{w}$ in (1)-(2b) are not germane to the estimation procedure, so we will introduce some simplifications. We will first discuss a simple version and then show how we incorporate the sum of earnings as a covariate in (6) when also including earnings separately in the first stage.

Consider the following structural model:

$$
\begin{aligned}
& \text { (A.1a) } y^{*}=\quad X_{1} \alpha_{1}+X \delta_{1}+u_{1} \\
& \text { (A.1b) } z^{*}=y y^{*}+X_{2} \alpha_{2}+X \delta_{2}+u_{2} .
\end{aligned}
$$

Equation (A.1a) is the analog to (1), except with $\alpha_{1}$ and $\delta_{1}$ representing $\bar{\alpha}_{1}$ and $\bar{\delta}_{1}$ as defined in (5a), while (A.1b) is the analog to (6). $X_{1}$ are variables that only appear in the first equation (or, as we call it sometimes, the first stage), $X_{2}$ are variables that only appear in the second equation, and $X$ are variables that appear in both. The parameter $\gamma$ is a scalar, and $\alpha_{1}, \alpha_{2}, \delta_{1}$, and $\delta_{2}$ may be scalars or vectors. Substitute (A.1a) into (A.1b) to obtain

$$
z^{*}=\gamma X_{1} \alpha_{1}+X_{2} \alpha_{2}+X\left(\gamma \delta_{1}+\delta_{2}\right)+\gamma u_{1}+u_{2} .
$$

We can now write the reduced form of the structural equation (A.1b) as

$$
\text { (A.2) } z^{*}=X_{1} \pi_{1}+X_{2} \pi_{2}+X \pi_{3}+e \text {. }
$$

We can estimate (A.1a) to obtain consistent estimates of $\hat{\alpha}_{1}$ and $\hat{\delta}_{1}$ and (A.2) to obtain consistent estimates of $\hat{\pi}_{1}, \hat{\pi}_{2}, \hat{\pi}_{3}$, and the covariance matrix $\hat{\Omega}_{e}$. Note that $y^{*}$ and $z^{*}$ may be either continuous or discrete; in our case, (A.1a) is an ordered probit and (A.2) takes the form of, variously, probit, tobit, and OLS.

The relationship between the structural and reduced form parameters is

$$
\begin{array}{ll}
\text { (A.3a) } \pi_{1}=\gamma \alpha_{1} \\
\text { (A.3b) } \pi_{2}=\alpha_{2} \\
\text { (A.3c) } \pi_{3}=\gamma \delta_{1}+\delta_{2} .
\end{array}
$$

(A.3b) identifies the structural parameters $\alpha_{2}$. In regards to the rest, Amemiya proposes using the consistent estimates of $\hat{\pi}_{1}, \hat{\pi}_{3}, \hat{\alpha}_{1}$, and $\hat{\delta}_{1}$ in order to estimate $\hat{\gamma}$ and $\hat{\delta}_{2}$ by generalized least squares (GLS), with $\hat{\Omega}_{e}$ as the weighting matrix. He shows that this approach is more 
efficient than the two-stage estimator proposed by Nelson and Olsen (1977) and elaborated by Maddala (1983, Section 8.8).

Now, we will discuss how to incorporate the sum of household earnings as a covariate in (A.1b) when each spouse's earnings are covariates in (A.1a). We will rewrite the equations as

$$
\begin{aligned}
& \left(\text { A. } 1 \mathrm{a}^{\prime}\right) y^{*}=X_{1}^{1} \alpha_{1}^{1}+X_{1}^{2} \alpha_{1}^{2}+X_{1}^{o} \alpha_{1}^{o}+X \delta_{1}+u_{1} \\
& \left(\text { A. } 1 b^{\prime}\right) z^{*}=\gamma y^{*}+\left(X_{1}^{1}+X_{1}^{2}\right) \delta_{3}+X_{2} \alpha_{2}+X \delta_{2}+u_{2} .
\end{aligned}
$$

We have now decomposed $X_{1}$ into $X_{1}^{1}$ and $X_{1}^{2}$ (which will represent the husband's and the wife's earnings) and $X_{1}^{o}$ (other variables that will only appear in the first equation). Moreover, the sum $X_{1}^{1}+X_{1}^{2}$ (total household earnings) now appears in the second equation. Once again, we can substitute to obtain

$$
z^{*}=X_{1}^{1}\left(\gamma \alpha_{1}^{1}+\delta_{3}\right)+X_{1}^{2}\left(\gamma \alpha_{1}^{2}+\delta_{3}\right)+\gamma X_{1}^{o} \alpha_{1}^{o}+X_{2} \alpha_{2}+X\left(\gamma \delta_{1}+\delta_{2}\right)+\gamma u_{1}+u_{2}
$$

and then write the reduced form of the structural equation $\left(\mathrm{A}^{\prime} 1 \mathrm{~b}^{\prime}\right)$ as

$$
\left(\text { A. } 2^{\prime}\right) z^{*}=X_{1}^{1} \pi_{1}^{1}+X_{1}^{2} \pi_{1}^{2}+X_{1}^{o} \pi_{1}^{o}+X_{2} \pi_{2}+X \pi_{3}+e .
$$

The relationship between the structural and reduced form parameters is now
(A.4a) $\pi_{1}^{1}=\gamma \alpha_{1}^{1}+\delta_{3}$
(A.4b) $\pi_{1}^{2}=\gamma \alpha_{1}^{2}+\delta_{3}$
(A.4c) $\pi_{1}^{o}=\gamma \alpha_{1}^{o}$
(A.4d) $\pi_{2}=\alpha_{2}$
(A.4e) $\pi_{3}=\gamma \delta_{1}+\delta_{2}$.

We can proceed in the same way as before. We estimate (A.1 $\left.\mathrm{a}^{\prime}\right)$ to obtain $\hat{\alpha}_{1}^{1}, \hat{\alpha}_{1}^{2}$, and $\hat{\alpha}_{1}^{o}$. We estimate (A.2') to obtain $\hat{\pi}_{1}^{1}, \hat{\pi}_{1}^{2}, \hat{\pi}_{1}^{o}, \hat{\pi}_{2}, \hat{\pi}_{3}$, and $\hat{\Omega}_{e}$. Lastly, we estimate the system (A.4a), (A.4b), (A.4c), and (A.4e) using GLS to obtain the remaining structural parameters in (A.1b').

To sum up, we use the methods that we outlined earlier in the Appendix to estimate the parameters reported in Table 7, with (A.1b) taking the form of a probit or tobit. We estimate a yet more generalized version of $\left(\mathrm{A} .1 \mathrm{~b}^{\prime}\right)$ for Table 6 , adding additional terms that interact $y^{*}$ with elements of $X$ - specifically, the husband's age and wife's age. As a consequence of these interactions, (A. $\left.2^{\prime}\right)$ involves terms that interact age with the error term $e$, so we use the HuberWhite method to estimate the covariance matrix $\hat{\Omega}_{e}$.

For the results in both tables, we also try different specifications of the first-stage equation (A.1a). When we use specifications that include each spouse's current or average past earnings in the first stage, then we include the sum of earnings in the second stage. While we would prefer the log of the sum of earnings, including this non-linear transformation of first-stage covariates is not possible using the method we have outlined above. As an alternative, we consider a first-stage specification of (A.1a) with the ratio of spouses' earnings, and then we can use the log of the sum of earnings as a covariate in the second stage. 


\section{REFERENCES}

Amemiya, Takeshi. 1979. "The Estimation of a Simultaneous-Equation Tobit Model." International Economic Review 20 (1): 169-181.

Barsky, Robert, F. Thomas Juster, Miles Kimball, and Matthew Shapiro. 1997. "Preference Parameters and Behavioral Heterogeneity: An Experimental Approach in the Health and Retirement Study." Quarterly Journal of Economics 112 (2): 537-579.

Behrman, Jere. 1995. "Intrahousehold Distribution and the Family," in M.Rosenzweig and O.Stark, eds., Handbook of Population and Family Economics. Amsterdam: North-Holland, pp.

Bergstrom, Theodore. 1995. "A Survey of Theories of the Family," in M.Rosenzweig and O.Stark, eds., Handbook of Population and Family Economics. Amsterdam: North-Holland, pp.

Bergstrom, Theodore. 1996. "Economics in a Family Way." Journal of Economic Literature 34 (4): 1903-1934.

Brien, Michael, Lee Lillard, and Steven Stern. 2004. “Cohabitation, Marriage, and Divorce in a Model of Match Quality.” Manuscript, University of Virginia, March.

Browning, Martin. 2000. "The Saving Behaviour of a Two-Person Household." Scandinavian Journal of Economics 102 (2): 235-251.

Browning, Martin, Francois Bourguignon, Pierre-André Chiappori, and Valérie Lechene. 1994. "Income and Outcomes: A Structural Model of Intrahousehold Allocation." Journal of Political Economy. 102 (6): 1067-96.

Browning, Martin, and Pierre-André Chiappori. 1998. "Efficient Intra-Household Allocations: A General Characterisation and Empirical Tests.” Econometrica. 66 (6): 1241-1278.

Bureau of Labor Statistics. 2004. "American Time-Use Survey Summary." Press release, September 14, http://www.bls.gov/news.release/atus.nr0.htm.

Duflo, Esther. 2003. "Grandmothers and Granddaughters: Old Age Pension and IntraHousehold Allocation in South Africa." World Bank Economic Review 17 (1): 1-25.

Duflo, Esther, and Christopher Udry. 2004. "Intrahousehold Resource Allocation in Côte d'Ivoire: Social Norms, Separate Accounts and Consumption Choices." National Bureau of Economics Research Working Paper No. 10498.

Flinn, Christopher. Forthcoming. "Minimum Wage Effects on Labor Market Outcomes under Search, Bargaining, and Endogenous Contact Rates." Econometrica.

Friedberg, Leora, and Steven Stern. 2005. "Marriage, Divorce, and Asymmetric Information." Draft, University of Virginia. 
Gourinchas, Pierre-Olivier, and Jonathan Parker. 2002. "Consumption Over The Life Cycle." Econometrica 70 (1): 47-89.

Greene, William. 2000. Econometric Analysis, Fourth edition. Upper Saddle River, NJ: Prentice-Hall, Inc.

Haddad Lawrence, and John Hoddinott. 1994. "Women's Income and Boy-Girl Anthropometric Status in the Cóte d'Ivoire." World Development 22 (4): 543-553.

Hersch, Joni. 1996. "Smoking, Seat Belts and Other Risky Consumer Decisions: Differences by Gender and Race." Managerial and Decision Economics 17 (5): 471-481.

Hoddinott, John and Lawrence Haddad. 1995. "Does Female Income Share Influence Household Expenditures? Evidence from Cóte d'Ivoire." Oxford Bulletin of Economics and Statistics 57(1): 77-96.

Jianakoplos, Nancy, and Alexandra Bernasek. 1998. “Are Women More Risk Averse?” Economic Inquiry 36 (4): 620-630.

Lundberg, Shelley, and Robert Pollak. 1996. "Bargaining and Distribution in Marriage." Journal of Economic Perspectives 10 (4): 139-158.

Lundberg, Shelley, Robert Pollak, and Terence Wales. 1997. "Do Husbands and Wives Pool Resources: Evidence from the UK Child Benefit." Journal of Human Resources 32 (3): 463 480.

Lundberg, Shelley, Richard Starz, and Steven Stillman. 2003. "The Retirement Consumption Puzzle: A Marital Bargaining Approach.” Journal of Public Economics 87 (5-6): 1119-1218.

Lyons, Angela, and Tansel Yilmazer. 2004. "How Does Marriage Affect the Allocation of Assets in Women's Defined Contribution Plans?" Center for Retirement Research at Boston College, CRR Working Paper 2004-28, November.

Maddala, G.S. 1983. Limited-Dependent and Qualitative Variables in Econometrics. Cambridge: Cambridge University Press.

Manser, Marilyn, and Murray Brown. 1980. "Marriage and Household Decision Making: A Bargaining Analysis." International Economic Review 21: 31-44.

McElroy, Marjorie and Mary Horney. 1981. "Nash-Bargained Decisions: Toward a Generalization of the Theory of Demand." International Economic Review 22: 333-349.

McElroy, Marjorie. 1981. “Appendix: Empirical Results from Estimates of Joint Labor Supply Functions of Husbands and Wives," in R.Ehrenberg, ed., Research in Labor Economics, Volume 4, pp. 53-64. Greenwich, CT: JAI Press.

National Economic Council. 1998. "Women and Retirement Security." Prepared by the Interagency Working Group on Social Security, http://www.ssa.gov/history/pdf/sswomen.pdf. 
Nelson, F., and L. Olson. 1977. "Specification and Estimation of a Simultaneous-Equation Model with Limited Dependent Variables." Social Science Working Paper No. 149, California Institute of Technology.

Phipps, Shelley, and Peter Burton. 1998. "What's Mine is Yours? The Influence of Male and Female Incomes on Patterns of Household Expenditure." Economica 65: 599-613.

President's Commission to Strengthen Social Security. 2001. "Strengthening Social Security and Creating Private Wealth for All Americans: Report of the President's Commission." Washington, December 21, http://csss.gov/reports/Final_report.pdf.

Rose, Elaina. 1999. "Consumption Smoothing and Excess Female Mortality in Rural India." Review of Economics and Statistics 81 (1): 41-49.

Schultz, T. Paul. 1990. "Testing the Neoclassical Model of Family Labor Supply and Fertility." Journal of Human Resources 25 (4): 599-634.

Thomas, Duncan. 1990. "Intra-Household Resource Allocation: An Inferential Approach." Journal of Human Resources 25 (4): 635-664.

Thomas, Duncan. 1994. "Like Father, Like Son, Like Mother, Like Daughter: Parental Resources and Child Height." Journal of Human Resources 29 (4): 950-988.

Ward-Batts, Jennifer. 2003. "Out of the Wallet and into the Purse: Using Micro Data to Test Income Pooling." Claremont Colleges Working Paper No. 2003-10. 
TABLE 1

Distribution of decision making power in the HRS sample

\begin{tabular}{l|cccc}
\hline \multicolumn{5}{c}{ "When it comes to making major family decisions, who has the final say?" } \\
\hline & \multicolumn{4}{|c}{ Husband reports ... has more say: } \\
husband & about equal & wife & Total [N] \\
\cline { 2 - 6 } Wife reports ... & $18.1 \%$ & 11.5 & 2.3 & $31.9[1350]$ \\
$\quad$ husband & 8.8 & 40.1 & 3.9 & $52.8[2235]$ \\
about equal & 3.3 & 6.5 & 5.5 & $15.3[652]$ \\
wife & $30.2[1278]$ & $58.1[2460]$ & $11.7[499]$ & $100 \%[4237]$ \\
Total [N] & &
\end{tabular}

"Does ... have a lot more say, somewhat more, or only a little more?"

\begin{tabular}{|c|c|c|c|c|c|c|}
\hline \multirow{3}{*}{$\begin{array}{l}\text { Wife reports ... } \\
\text { husband - a lot more } \\
\text { husband - somewhat/ } \\
\text { a little more }\end{array}$} & \multirow{3}{*}{ 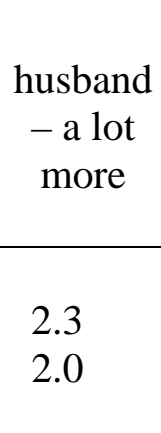 } & \multicolumn{3}{|c|}{\begin{tabular}{lcc}
\multicolumn{3}{l}{ Husband reports ... has ... say: } \\
husband - & about & wife - \\
somewhat & equal & somewhat \\
/a little & & / a little \\
more & & more \\
\end{tabular}} & $\begin{array}{c}\text { wife - } \\
\text { a lot } \\
\text { more }\end{array}$ & Total \\
\hline & & 3.3 & 2.4 & 0.3 & 0.3 & 8.6 \\
\hline & & 10.4 & 9.0 & 1.1 & 0.5 & 23.0 \\
\hline about equal & 1.7 & 7.1 & 40.2 & 2.8 & 1.1 & 52.9 \\
\hline $\begin{array}{l}\text { wife - somewhat/ } \\
\text { a little more }\end{array}$ & 0.3 & 1.9 & 3.9 & 2.0 & 0.8 & 8.9 \\
\hline wife - a lot more & 0.3 & 0.9 & 2.7 & 1.5 & 1.2 & 6.6 \\
\hline Total & 6.6 & 23.6 & 58.2 & 7.7 & 3.9 & $100 \%$ \\
\hline
\end{tabular}

Data: Health and Retirement Study, Wave 1, 1992.

Sample: $N=4237$. See text for more details. 
TABLE 2

Characteristics of the sample, based on who has more say

\begin{tabular}{l|cccc|}
\hline & \multicolumn{4}{|c}{ Who has more say? } \\
& Husband & Wife & $\begin{array}{c}\text { About } \\
\text { equal }\end{array}$ & Disagree \\
\cline { 2 - 4 } Income, work variables: & & & & \\
both spouses work & 42.1 & 39.4 & 46.4 & 43.9 \\
only husband works & 29.1 & 22.0 & 24.6 & 25.7 \\
only wife works & 9.1 & 22.0 & 13.3 & 15.4 \\
neither spouse works & 19.7 & 16.6 & 15.9 & 15.0 \\
husband's weekly hours & 44.0 & 44.0 & 44.2 & 45.0 \\
wife's weekly hours & 34.2 & 39.4 & 37.3 & 36.8 \\
husband's earnings & 31,100 & 25,000 & 32,000 & 30,000 \\
wife's earnings & 12,000 & 19,000 & 17,000 & 15,000 \\
Other variables: & & & & \\
income & 45,700 & 41,216 & 49,200 & 46,360 \\
net worth & 121,700 & 65,700 & 132,000 & 117,500 \\
financial assets (median/mean) & $8,000 /$ & $3,000 /$ & $10,500 /$ & $8,900 /$ \\
& 43,500 & 22,676 & 50,451 & 49.850 \\
\% of financial assets invested in & $0.0 / 17.9$ & $0.0 / 10.4$ & $0.0 / 18.3$ & $0.0 / 17.2$ \\
$\quad$ equity (median/mean) & & & & \\
\hline
\end{tabular}

Data: Health and Retirement Study, Wave 1, 1992.

Sample: $N=4237$. See text for more details. 
TABLE 3-A

Determinants of decision making power

Estimation results from bivariate ordered probits

Dependent variable: Respondent reports husband has final say $\left(\mathrm{Y}_{\mathrm{i}}=1\right)$, it's about equal $\left(Y_{i}=0\right)$, wife has final say $\left(Y_{i}=-1\right)$

\begin{tabular}{|c|c|c|c|c|}
\hline \multirow{3}{*}{ Log likelihood (LL/N) } & \multicolumn{2}{|c|}{ Husband is respondent } & \multicolumn{2}{|c|}{ Wife is respondent } \\
\hline & \multicolumn{4}{|c|}{-1.801} \\
\hline & \multicolumn{4}{|c|}{$0.4545^{* * *}(0.0257)$} \\
\hline Threshold value $\mu_{0}$ & $-1.2745^{* * *}$ & $(0.1864)$ & $-1.1504^{* * *}$ & $(0.1929)$ \\
\hline Threshold value $\mu_{1}$ & $0.4921^{* * *}$ & $(0.1887)$ & $0.3966^{* *}$ & $(0.1924)$ \\
\hline \multicolumn{5}{|l|}{ Income variables } \\
\hline husband's earnings/10,000 & 0.0072 & $(0.0053)$ & $0.0150^{* * *}$ & $(0.0054)$ \\
\hline wife's earnings $/ 10,000$ & $-0.0356^{* *}$ & $(0.0149)$ & $-0.0753^{* * *}$ & $(0.0149)$ \\
\hline husband's pension income/10,000 & 0.0360 & $(0.0312)$ & 0.0435 & $(0.0289)$ \\
\hline wife's pension income/10,000 & -0.1072 & $(0.1118)$ & -0.1212 & $(0.0986)$ \\
\hline husband has pension in current job & 0.0123 & $(0.0511)$ & 0.0196 & $(0.0518)$ \\
\hline \multirow[t]{2}{*}{ wife has pension in current job } & -0.0595 & $(0.0526)$ & 0.0365 & $(0.0538)$ \\
\hline & \multicolumn{2}{|c|}{ Characteristics of: } & \multicolumn{2}{|c|}{ Characteristics of: } \\
\hline \multirow{3}{*}{$\begin{array}{l}\text { Other work variables } \\
\text { occupation: professional, tech }\end{array}$} & husband & wife & husband & wife \\
\hline & $0.1352^{*}$ & -0.0641 & 0.1039 & -0.0693 \\
\hline & $(0.0726)$ & $(0.0726)$ & $(0.0728)$ & $(0.0723)$ \\
\hline \multirow[t]{2}{*}{ sales, clerical } & 0.0998 & -0.0228 & 0.0067 & 0.0306 \\
\hline & $(0.0816)$ & $(0.0613)$ & $(0.0821)$ & $(0.0620)$ \\
\hline \multirow[t]{2}{*}{ services } & 0.0357 & -0.0241 & -0.1288 & -0.0727 \\
\hline & $(0.0877)$ & $(0.0674)$ & $(0.0922)$ & $(0.0716)$ \\
\hline \multirow[t]{2}{*}{ skilled blue collar } & -0.0982 & 0.1744 & $-0.1333^{*}$ & -0.0448 \\
\hline & $(0.0714)$ & $(0.1658)$ & $(0.0731)$ & $(0.1658)$ \\
\hline \multirow[t]{2}{*}{ unskilled blue collar } & -0.1085 & 0.0547 & $-0.1519^{* *}$ & -0.0740 \\
\hline & $(0.0707)$ & $(0.0897)$ & $(0.0727)$ & $(0.0947)$ \\
\hline \multirow[t]{2}{*}{ self-employed } & $0.3442^{* * *}$ & $-0.1153^{*}$ & $0.2133^{* * *}$ & -0.0425 \\
\hline & $(0.0603)$ & $(0.0683)$ & $(0.0627)$ & $(0.0716)$ \\
\hline \multicolumn{5}{|l|}{ Human capital variables } \\
\hline \multirow[t]{2}{*}{ cognition: score \#1 } & 0.0032 & -0.0025 & 0.0120 & -0.0077 \\
\hline & $(0.0079)$ & $(0.0073)$ & $(0.0080)$ & $(0.0075)$ \\
\hline \multirow[t]{2}{*}{ score \#2 } & $0.0159^{* *}$ & -0.0115 & 0.0015 & 0.0016 \\
\hline & $(0.0073)$ & $(0.0076)$ & $(0.0074)$ & $(0.0077)$ \\
\hline \multirow[t]{2}{*}{ education: no high school diploma } & $-0.1529^{* * *}$ & 0.0740 & $-0.1466^{* * * *}$ & $0.1374^{* * *}$ \\
\hline & $(0.0503)$ & $(0.0510)$ & $(0.0524)$ & $(0.0542)$ \\
\hline \multirow[t]{2}{*}{ at least some college } & $0.0806^{*}$ & -0.0780 & 0.0074 & -0.0571 \\
\hline & $(0.0487)$ & $(0.0481)$ & $(0.0491)$ & $(0.0494)$ \\
\hline \multirow[t]{2}{*}{ health is fair or poor } & 0.0087 & -0.0197 & 0.0228 & 0.0167 \\
\hline & $(0.0475)$ & $(0.0507)$ & $(0.0507)$ & $(0.0525)$ \\
\hline \multirow[t]{2}{*}{ both parents: no high school dipl } & -0.0114 & 0.0121 & 0.0402 & 0.0294 \\
\hline & $(0.0373)$ & $(0.0386)$ & $(0.0383)$ & $(0.0394)$ \\
\hline \multirow[t]{2}{*}{ at least some college } & $-0.1646^{*}$ & $-0.1454^{*}$ & -0.0679 & -0.1065 \\
\hline & $(0.0909)$ & $(0.0837)$ & $(0.0948)$ & $(0.0814)$ \\
\hline
\end{tabular}




\begin{tabular}{l|cccc|} 
Cultural background variables & \multicolumn{4}{c}{} \\
national origin: born outside U.S. & $0.1896^{* *}$ & $-0.2288^{* * *}$ & 0.0157 & -0.1025 \\
race: black & $(0.0891)$ & $(0.0817)$ & $(0.0902)$ & $(0.0854)$ \\
& $0.4748^{* *}$ & $-0.3932^{*}$ & 0.0404 & -0.3176 \\
ethnicity: hispanic & $(0.2000)$ & $(0.2017)$ & $(0.2280)$ & $(0.2308)$ \\
& 0.1077 & 0.1617 & -0.0517 & 0.0685 \\
religion: attend church $\geq$ twice/mth & $(0.1193)$ & $(0.1169)$ & $(0.1250)$ & $(0.1228)$ \\
& $0.0804^{*}$ & $0.0918^{* *}$ & $0.0873^{*}$ & 0.0529 \\
both are Protestant & $(0.0454)$ & $(0.0452)$ & $(0.0469)$ & $(0.0468)$ \\
both are Evangelical & $0.2295^{* * *}$ & $(0.0740)$ & $0.2060^{* * *}(0.0807)$ \\
both are Catholic & $0.3746^{* *}$ & $(0.1535)$ & $0.5177^{* * *}$ & $(0.1583)$ \\
both are Jewish & $-0.1126^{* *}$ & $(0.0499)$ & $-0.1722^{* * *}$ & $(0.0501)$ \\
both report no religion & 0.1874 & $(0.1331)$ & -0.0454 & $(0.1353)$ \\
religion differs & -0.2177 & $(0.1746)$ & -0.0974 & $(0.1634)$ \\
Other variables & 0.0515 & $(0.0487)$ & $-0.1220^{* * *}$ & $(0.0500)$ \\
risk averse & & & & \\
long time horizon & $0.0279^{*}$ & 0.0014 & -0.0099 & -0.0010 \\
& $(0.0165)$ & $(0.0170)$ & $(0.0170)$ & $(0.0175)$ \\
age-50 & -0.0247 & 0.0305 & -0.0157 & 0.0411 \\
& $(0.037)$ & $(0.0378)$ & $(0.0378)$ & $(0.0390)$ \\
has kids: over age 18 only & $-0.0079^{* *}$ & $-0.0081^{* *}$ & -0.0013 & -0.0015 \\
age 18 \& under only & $(0.0040)$ & $(0.0039)$ & $(0.0042)$ & $(0.0041)$ \\
over and under age 18 & -0.1109 & $(0.1033)$ & -0.0010 & $(0.1035)$ \\
\hline
\end{tabular}

Data: Health and Retirement Study, 1992.

Sample: $\mathrm{N}=4237$. Statistical significant at the $90 \%(*), 95 \%(* *)$, and $99 \%(* * *)$ level is noted. See text for more details. 


\section{TABLE 3-B}

Determinants of decision making power Variations on specification of earnings variable

Dependent variable: Respondent reports husband has final say $\left(Y_{\mathrm{i}}=1\right)$, it's about equal $\left(\mathrm{Y}_{\mathrm{i}}=0\right)$, wife has final say $\left(\mathrm{Y}_{\mathrm{i}}=-1\right)$

\begin{tabular}{|c|c|c|c|}
\hline \multirow{3}{*}{ Log likelihood/N } & $\begin{array}{l}\text { (1) current earnings } \\
\text { (from Table 3-A) }\end{array}$ & $\begin{array}{l}\text { (2) average past } \\
\text { earnings }\end{array}$ & $\begin{array}{l}\text { (3) current, average } \\
\text { past earnings }\end{array}$ \\
\hline & -1.801 & -1.790 & -1.792 \\
\hline & \multicolumn{3}{|c|}{ Husband is respondent } \\
\hline Threshold value $\mu_{0}$ & $-1.2745(0.1864)$ & $-1.1133(0.2230)$ & $-1.1515(0.2242)$ \\
\hline Threshold value $\mu_{1}$ & $0.4921(0.1887)$ & $0.6658(0.2255)$ & $0.6218(0.2264)$ \\
\hline \multirow{3}{*}{$\begin{array}{l}\text { Earnings variables } \\
\text { current earnings } / 10,000 \\
\text { husband } \\
\text { wife }\end{array}$} & & & \\
\hline & $0.0072(0.0053)$ & - & $0.0053 \quad(0.0065)$ \\
\hline & $-0.0356^{* *}(0.0149)$ & - & $-0.0301^{*}(0.0178)$ \\
\hline \multirow{4}{*}{$\begin{array}{l}\text { average past earnings } / 10,000 \\
\text { husband } \\
\text { wife }\end{array}$} & & 1951-1991 & age $22-45$ \\
\hline & - & $0.0114(0.0244)$ & $\begin{array}{ll}0.0011 & (0.0297)\end{array}$ \\
\hline & - & $-0.1106^{* * * *}(0.0440)$ & $-0.0173(0.0318)$ \\
\hline & \multicolumn{3}{|c|}{ Wife is respondent } \\
\hline Threshold value $\mu_{0}$ & $-1.1504(0.1929)$ & $-1.1235(0.2345)$ & $-1.0600(02443)$ \\
\hline Threshold value $\mu_{1}$ & $0.3966(0.1924)$ & $0.4428(0.2345)$ & $0.5245(0.2458)$ \\
\hline \multicolumn{4}{|l|}{$\begin{array}{l}\text { Earnings variables } \\
\text { current earnings } / 10,000\end{array}$} \\
\hline husband & $0.0150^{* * * *}(0.0054)$ & - & 0.0098 \\
\hline wife & $-0.0753^{* * * *}(0.0149)$ & - & $-0.0678^{* * *}(0.0181)$ \\
\hline $\begin{array}{l}\text { average past earnings/10,000 } \\
\text { husband }\end{array}$ & & 1951-1991 & age $22-45$ \\
\hline $\begin{array}{l}\text { husband } \\
\text { wife }\end{array}$ & - & $\begin{array}{r}0.02000^{* * *}(0.0244) \\
-0.2405^{* *}(0.0442)\end{array}$ & $\begin{array}{l}-0.0048 \\
-0.0797^{* * *}(0.0303) \\
(0.0312)\end{array}$ \\
\hline
\end{tabular}

Data: Health and Retirement Study, Wave 1, 1992.

Sample: $\mathrm{N}=3087$ in columns (2), (3). All specifications include on the right-hand side all of the other variables shown in Table 3-A. See text for more details. 
TABLE 3-C: Determinants of decision making power Variations on specification of work variables

Dependent variable: Respondent reports husband has final say $\left(\mathrm{Y}_{\mathrm{i}}=1\right)$, it's about equal $\left(Y_{i}=0\right)$, wife has final say $\left(Y_{i}=-1\right)$

\begin{tabular}{|c|c|c|c|c|c|}
\hline & $\begin{array}{l}\text { (1) weekly } \\
\text { work hours }\end{array}$ & $\begin{array}{l}\text { (2) work } \\
\text { (no occ } \\
\text { dummies) }\end{array}$ & $\begin{array}{c}\text { (3) only } \\
\text { work } \\
\text { variables }\end{array}$ & $\begin{array}{l}\text { (4) } \log \text { of } \\
\text { earnings }\end{array}$ & $\begin{array}{l}\text { (5) ratio of } \\
\text { earnings }\end{array}$ \\
\hline Log likelihood (LL/N) & -1.799 & -1.810 & -1.830 & -1.803 & -1.799 \\
\hline Selected work variables & \multicolumn{5}{|c|}{ Husband is respondent } \\
\hline husband's earnings/10,000 & $\begin{array}{c}0.0064 \\
(0.0054)\end{array}$ & $\begin{array}{l}0.0116^{\sqrt{*}} \\
(0.0052)\end{array}$ & $\begin{array}{l}0.0111 \\
(0.0051)\end{array}$ & $\begin{array}{c}0.0094 \\
(0.0060)\end{array}$ & $\begin{array}{c}0.0036 \\
(0.0058)\end{array}$ \\
\hline wife's earnings $/ 10,000$ & $\begin{array}{l}-0.0256^{*} \\
(0.0153)\end{array}$ & $\begin{array}{c}-0.0364^{* * *} \\
(0.0145)\end{array}$ & $\begin{array}{c}-0.0342^{* *} \\
(0.0145)\end{array}$ & $\begin{array}{l}-0.0205^{* * *} \\
(0.0063)\end{array}$ & $\begin{array}{l}-0.0133 \\
(0.0169)\end{array}$ \\
\hline wife's earnings & - & - & - & - & $-0.2402^{* * *}$ \\
\hline husband's+wife's earnings & & & & & $(0.0923)$ \\
\hline $\begin{array}{l}\text { husband's+wife's } \\
\text { earnings }=0\end{array}$ & - & - & - & - & $\begin{array}{c}0.0358 \\
(0.0776)\end{array}$ \\
\hline husband works & - & $\begin{array}{c}0.1388^{* * *} \\
(0.0498)\end{array}$ & - & - & - \\
\hline wife works & - & $\begin{array}{l}-0.0365 \\
(0.0461)\end{array}$ & - & - & - \\
\hline husband's weekly hours & $\begin{array}{l}-0.0007 \\
(0.0014)\end{array}$ & - & - & - & - \\
\hline wife's weekly hours & $\begin{array}{l}-0.0042^{* * * *} \\
(0.0016)\end{array}$ & - & - & - & - \\
\hline & \multicolumn{5}{|c|}{ Wife is respondent } \\
\hline husband's earnings & $\begin{array}{r}0.0136 \\
(0.0054)\end{array}$ & $\begin{array}{l}0.0204^{* * *} \\
(0.0053)\end{array}$ & $\begin{array}{l}0.0129 \\
(0.0052)\end{array}$ & $\begin{array}{c}0.0275 \\
(0.0369)\end{array}$ & $\begin{array}{c}0.0117 \\
(0.0058)\end{array}$ \\
\hline wife's earnings & $\begin{array}{l}-0.0613^{*} \\
(0.0155)\end{array}$ & $\begin{array}{c}-0.0762^{* * * *} \\
(0.0146)\end{array}$ & $\begin{array}{l}-0.0856^{* *} \\
(0.0148)\end{array}$ & $\begin{array}{l}-0.0340^{* * *} \\
(0.0377)\end{array}$ & $\begin{array}{l}-0.0526^{* * *} \\
(0.0168)\end{array}$ \\
\hline wife's earnings & - & - & - & - & $-0.2412^{* * *}$ \\
\hline husband's+wife's earnings & & & & & $(0.0945)$ \\
\hline $\begin{array}{l}\text { husband's+wife's } \\
\text { earnings }=0\end{array}$ & - & - & - & - & $\begin{array}{c}0.0450 \\
(0.0785)\end{array}$ \\
\hline husband works & - & $\begin{array}{l}-0.0455 \\
(0.0515)\end{array}$ & - & - & - \\
\hline wife works & - & $\begin{array}{l}-0.0299 \\
(0.0476)\end{array}$ & - & - & - \\
\hline husband's weekly hours & $\begin{array}{c}0.0001 \\
(0.0015)\end{array}$ & - & - & - & - \\
\hline wife's weekly hours & $\begin{array}{l}-0.0065^{\text {**** }} \\
(0.0018)\end{array}$ & - & - & - & - \\
\hline Also includes:occ,self-empl & yes & no & yes & yes & yes \\
\hline other control variables & yes & yes & no & yes & yes \\
\hline
\end{tabular}

Data: Health and Retirement Study, Wave 1, 1992. Sample: $\mathrm{N}=4237$. Except as noted, all specifications include on the right-hand side all of the other variables shown in Table 3-A. See text for more details. 
TABLE 4

Decomposition of estimated determinants of decision making power Estimation results from Table 3-A

Dependent variable: Respondent reports husband has final say $\left(Y_{i}=1\right)$, it's about equal $\left(\mathrm{Y}_{\mathrm{i}}=0\right)$, wife has final say $\left(\mathrm{Y}_{\mathrm{i}}=-1\right)$

\section{Income variables}

husband's earnings/10,000

wife's earnings $/ 10,000$

husband's pension income/10,000

wife's pension income/10,000

husband has pension in current job

wife has pension in current job

\section{Other work variables}

occupation: professional, technical sales, clerical

services

skilled blue collar

unskilled blue collar

self-employed

Human capital: cognition score \#1 score \#2

education: no high school diploma at least some college

health is fair or poor

both parents: no high sch diploma at least some college

Cultural: born outside U.S.

race: black

ethnicity: hispanic

religion: attend church $\geq$ twice/mth

both are Protestant

both are Evang' $1 /$ Fundamentalist

both are Catholic

both are Jewish

both report no religion

religion differs

Other variables: risk averse

long time horizon

age-50

has kids: over age 18 only

age 18 \& under only

over and under age 18
True effect

Husband's reporting bias

Current earnings specification

$\begin{array}{rrrr}0.0111^{* * * *} & (0.0044) & -0.0039 & (0.0060) \\ -0.0555^{* * * *} & (0.0126) & 0.0198 & (0.0160) \\ 0.0397 & (0.0246) & -0.0038 & (0.0345) \\ -0.1142 & (0.0866) & 0.0070 & (0.1201) \\ 0.0160 & (0.0430) & -0.0037 & (0.0565) \\ -0.0115 & (0.0447) & -0.0480 & (0.0577)\end{array}$

Characteristics of husband: Characteristics of wife:

True Bias True Bias

$\begin{array}{llll}0.1196^{* *} & 0.0156 & -0.0667 & 0.0026\end{array}$

$\begin{array}{llll}0.0532 & 0.0466 & 0.0039 & -0.0267\end{array}$

$\begin{array}{llll}-0.0465 & 0.0756 & -0.0484 & 0.0243\end{array}$

$\begin{array}{llll}-0.1158^{* *} & 0.0176 & 0.0648 & 0.1096^{* *}\end{array}$

$\begin{array}{llll}-0.1302^{* *} & 0.0217 & -0.0096 & 0.0644\end{array}$

$\begin{array}{llll}0.2788^{* * *} & 0.0654 & -0.0789 & -0.0364\end{array}$

$\begin{array}{llll}0.0076 & -0.0044 & -0.0051 & 0.0026\end{array}$

$\begin{array}{llll}0.0087 & 0.0072 & -0.0049 & -0.0066\end{array}$

$\begin{array}{llll}-0.1497^{* * *} & -0.0032 & 0.1057^{* * *} & -0.0317 \\ 0.0440 & 0.0366 & -0.0676^{*} & -0.017\end{array}$

$\begin{array}{llll}0.0440 & 0.0366 & -0.0676^{*} & -0.0104\end{array}$

$\begin{array}{llll}0.0157 & -0.0071 & -0.0015 & -0.0182\end{array}$

$\begin{array}{llll}0.0144 & -0.0258 & 0.0207 & -0.0087\end{array}$

$\begin{array}{llll}-0.1163 & -0.0483 & -0.1259^{*} & -0.0195\end{array}$

$\begin{array}{llll}0.1027 & 0.0869 & -0.1656^{* * *} & -0.0631\end{array}$

$\begin{array}{llll}0.2576 & 0.2172 & -0.3554^{*} & -0.0378\end{array}$

$\begin{array}{llll}0.0280 & 0.0797 & 0.1151 & 0.0466\end{array}$

$\begin{array}{llll}0.0839^{* *} & -0.0034 & 0.0724^{*} & 0.0195\end{array}$

$0.2178^{* * * *} \quad 0.0117$

$0.4462^{* * *} \quad-0.0716$

$-0.1424^{* * * *} \quad 0.0298$

$0.0710 \quad 0.1164$

$-0.1576-0.0601$

$-0.0353 \quad 0.0868^{*}$

\begin{tabular}{crcc}
0.0090 & 0.0189 & 0.0002 & 0.0012 \\
-0.0202 & -0.0045 & 0.0358 & -0.0053 \\
-0.0046 & -0.0033 & -0.0049 & -0.0033 \\
-0.0560 & \multicolumn{2}{c}{-0.0549} \\
-0.2041 & -0.0425 \\
-0.0665 & -0.1213
\end{tabular}


Selected results

husband's earnings/10,000

wife's earnings $/ 10,000$
Average past earnings specification $3-\mathrm{B}(2)$

$\begin{array}{llll}0.0157 \quad(0.0205) & -0.0043 & (0.0270)\end{array}$

$-0.1756^{* * *}(0.0370) \quad 0.0650 \quad(0.0479)$

Data: Health and Retirement Study, Wave 1, 1992.

Sample: $N=4237$. See text for more details.

TABLE 5

Simulations of predicted decision making power

\begin{tabular}{|c|c|c|c|c|c|c|}
\hline & \multicolumn{3}{|c|}{ usband reports ... has more say } & \multicolumn{3}{|c|}{ Wife reports ... has more say } \\
\hline & husband & $\begin{array}{l}\text { about } \\
\text { equal }\end{array}$ & wife & husband & $\begin{array}{l}\text { about } \\
\text { equal }\end{array}$ & wife \\
\hline \multirow{2}{*}{ Actual values } & \multicolumn{6}{|c|}{$\begin{array}{l}\text { Based on specifications that control for current earnings, } \\
\text { work status (as in Table 3-C 2) }\end{array}$} \\
\hline & 0.302 & 0.580 & 0.118 & 0.319 & 0.527 & 0.154 \\
\hline $\begin{array}{l}\text { Baseline predictions } \\
\text { using own values of }\end{array}$ & 0.311 & 0.576 & 0.113 & 0.325 & 0.525 & 0.150 \\
\hline $\begin{array}{l}\text { using average values of } \\
\text { earnings, work status }\end{array}$ & 0.310 & 0.579 & 0.111 & 0.323 & 0.530 & 0.147 \\
\hline \multirow{6}{*}{$\begin{array}{l}\text { Predictions if ... } \\
\text { switch average earnings } \\
\text { switch earnings, work } \\
\text { husbands work, wives don't } \\
\text { wives work, husbands don't }\end{array}$} & & & & & & \\
\hline & 0.282 & 0.590 & 0.128 & 0.266 & 0.545 & 0.189 \\
\hline & 0.275 & 0.593 & 0.132 & 0.2 & 0.546 & 0.191 \\
\hline & 0.350 & 0.558 & 0.092 & 0.372 & 0.509 & 0.117 \\
\hline & 0.253 & 0.600 & 0.147 & 0.270 & 0.545 & 0.185 \\
\hline & \multicolumn{6}{|c|}{$\begin{array}{l}\text { Based on specifications that control for lifetime earnings, } \\
\text { work status (adapted from those in Table 3-B 2) }\end{array}$} \\
\hline $\begin{array}{l}\text { Baseline predictions } \\
\text { using own values of earnings, } \\
\text { work status }\end{array}$ & 0.298 & 0.582 & 0.120 & 0.318 & 0.530 & 0.153 \\
\hline $\begin{array}{l}\text { using average values of } \\
\text { earnings, work status }\end{array}$ & 0.298 & 0.584 & 0.119 & 0.315 & 0.535 & 0.149 \\
\hline $\begin{array}{l}\text { Predictions if ... } \\
\text { switch average earnings }\end{array}$ & 0.243 & & 0.155 & 0.197 & 0.551 & 0.253 \\
\hline switch earnings, work & 0.236 & 0.604 & 0.160 & 0.193 & 0.550 & 0.258 \\
\hline husbands work, wives don’t & 0.330 & 0.568 & 0.101 & 0.375 & 0.510 & 0.115 \\
\hline wives work, husbands don’t & 0.250 & 0.602 & 0.148 & 0.273 & 0.547 & 0.180 \\
\hline
\end{tabular}

Predicted probabilities, averaged over the estimation sample, based on the bivariate ordered probit estimates reported in Table 3. 
TABLE 6

Consequences of decision making power

Impact on wealth

Dependent variable: Log household wealth

Characteristics of husband: Characteristics of wife:

A. Use continuous information on true decision-making power $y^{*}$

husband's decision-making power age

husband's power*age

current household earnings

long time horizon

risk averse

husband's decision-making power age

husband's power*age

average household earnings

husband's decision-making power age

husband's power*age

$\log$ (current household earnings)

husband's decision-making power

Age

husband's power*age

$\log$ (average household earnings)

\section{Selected variables:}

husband's decision-making power age

husband's power*age

$\log$ (current household earnings)

long time horizon

risk averse

husband's decision-making power age

husband's power*age

$\log$ (average household earnings)

\begin{tabular}{|c|c|}
\hline (1) Efficient esti & orrect standard errors) \\
\hline \multicolumn{2}{|c|}{ Based on current earnings specification (3-A) } \\
\hline \multicolumn{2}{|c|}{$-0.0971 \quad(0.2471)$} \\
\hline $0.0284^{* * *}(0.0061)$ & $0.0383^{* * *}(0.0064)$ \\
\hline $0.0236 \quad(0.0155)$ & $-0.0234^{*}(0.0134)$ \\
\hline \multicolumn{2}{|c|}{$0.0622^{* * * *}(0.0061)$} \\
\hline $0.0973^{* * *}(0.0368)$ & $0.1295^{* * *}(0.0379)$ \\
\hline $0.0311^{*}(0.0179)$ & $0.0038 \quad(0.0183)$ \\
\hline \multicolumn{2}{|c|}{ Based on average past earnings specification (3-B 2) } \\
\hline \multicolumn{2}{|c|}{$0.8217^{* * * *}(0.2281)$} \\
\hline $0.0185^{* * * *}(0.0063)$ & $0.0404^{* * *}(0.0069)$ \\
\hline $0.0324^{* *}(0.0133)$ & $-0.0345^{* *}(0.0136)$ \\
\hline \multicolumn{2}{|c|}{$0.3162^{* * *}(0.0203)$} \\
\hline \multicolumn{2}{|c|}{$\begin{array}{c}\text { Based on ratio of earnings specification (3-C 5) } \\
\text { with control for current earnings }\end{array}$} \\
\hline \multicolumn{2}{|c|}{$0.2927 \quad(0.3111)$} \\
\hline $0.0288^{* * *}(0.0061)$ & $0.0400^{* * *}(0.0061)$ \\
\hline \multirow{2}{*}{\multicolumn{2}{|c|}{$0.3296^{* * *}(0.0357)$}} \\
\hline & \\
\hline \multicolumn{2}{|c|}{ with control for average past earnings } \\
\hline \multicolumn{2}{|c|}{$0.5442(0.3504)$} \\
\hline $0.0256^{* * *}(0.0068)$ & $0.0360^{* * *}(0.0070)$ \\
\hline $0.0253 \quad(0.0166)$ & $-0.0319^{* *}(0.0165)$ \\
\hline \multicolumn{2}{|c|}{$0.3555^{* * * *}(0.0493)$} \\
\hline \multicolumn{2}{|c|}{ (2) Two-stage estimation (incorrect standard errors) } \\
\hline \multicolumn{2}{|c|}{ Based on current earnings specification (3-A) } \\
\hline \multicolumn{2}{|c|}{$0.1528 \quad(0.2550)$} \\
\hline $0.0320^{* * *}(0.0072)$ & $0.0372^{* * * *}(0.0078)$ \\
\hline $0.0478^{* * *}(0.0193)$ & $-0.0415^{*}(0.0161)$ \\
\hline \multicolumn{2}{|c|}{$0.0256^{* * *}(0.0090)$} \\
\hline $0.1168^{* * * *}(0.0399)$ & $0.1313^{* * * *}(0.0409)$ \\
\hline $0.0279 \quad(0.0194)$ & $-0.0096 \quad(0.0202)$ \\
\hline \multicolumn{2}{|c|}{ Based on average past earnings specification (3-B 2) } \\
\hline & \\
\hline $0.0206^{* * *}(0.0079)$ & $0.0380^{* * *}(0.0090)$ \\
\hline $0.0440^{* *}(0.0175)$ & $-0.0359^{* *}(0.0165)$ \\
\hline
\end{tabular}




\begin{tabular}{|c|c|}
\hline \multirow{3}{*}{$\begin{array}{l}\text { husband's decision-making power } \\
\text { age } \\
\text { husband's power*age } \\
\text { log(current household earnings) }\end{array}$} & $\begin{array}{c}\text { Based on ratio of earnings specification (3-C 5) } \\
\text { with control for current earnings }\end{array}$ \\
\hline & $\begin{array}{llll} & 0.4064^{*}(0.2342) & \\
0.0338^{* * *}(0.0073) & 0.0374^{* * *}(0.0078) \\
0.0430^{* * *}(0.0181) & -0.0390^{* *}(0.0159)\end{array}$ \\
\hline & with control for average past earnings \\
\hline $\begin{array}{l}\text { husband's decision-making power } \\
\text { age } \\
\text { husband's power*age } \\
\text { log(average household earnings) }\end{array}$ & $\begin{array}{llcc} & 0.2092 & (0.2671) & \\
0.0263^{* * *}(0.0083) & 0.0344^{* * *} & (0.0090) \\
0.0414^{* *}(0.0194) & -0.0362^{*} & (0.0187) \\
& & 0.3698^{* * *}(0.0493) & \end{array}$ \\
\hline
\end{tabular}

B. Use discrete information on reported decision-making power $y^{h}, y^{w}$

husband reports: he has final say "about equal"

age-50

husband has final say *age

"about equal"*age

wife reports: he has final say

"about equal"

age-50

husband has final say *age

"about equal"*age
(1) Information reported by husband

$-0.0408 \quad(0.1239)$

$-0.1118 \quad(0.1129)$

$-0.0026(0.0131) \quad 0.0540^{\text {*** }}(0.0142)$

$0.0407^{* * *}(0.0150) \quad-0.0300^{* *}(0.0151)$

$0.0318^{* *}(0.0135) \quad-0.0139(0.0149)$

\section{(2) Information reported by wife}

$\begin{array}{ccc}0.0047 & (0.1113) & \\ 0.0436 & (0.1032) & \\ & 0.0512^{* * *} & (0.0122) \\ & -0.0294^{* *} & (0.0130) \\ & -0.0102 & (0.0122)\end{array}$

Data: Health and Retirement Study, 1992.

Sample: $\mathrm{N}=4077$ when current earnings are included or 2983 when average past earnings are included. Other control variables besides earnings are those reported in Table 3-A, along with subjective life expectancy. See text for more details. 
TABLE 7

Consequences of decision making power

Impact on stock market investments

Dependent variable: Household investment in equities

\begin{tabular}{|c|c|c|}
\hline \multirow{4}{*}{ Mean value } & $\begin{array}{c}\text { Probit } \\
\text { Invests in equities (1,0) } \\
\text { [marginal effect in brackets] }\end{array}$ & $\begin{array}{c}\text { Tobit } \\
\text { Share of financial assets } \\
\text { invested in equities }\end{array}$ \\
\cline { 2 - 3 } & 0.32 & 0.17 \\
\hline
\end{tabular}

A. Use continuous information on true decision-making power $y^{*}$

husband's decision-making power age-50: husband

wife

current household earnings

long time horizon: husband wife

risk averse: husband wife

\begin{tabular}{|c|c|}
\hline \multirow{2}{*}{\multicolumn{2}{|c|}{$\begin{array}{l}\text { (1) Efficient estimation (correct standard errors) } \\
\text { Based on current earnings specification (3-A) } \\
\text { Restrict effect of sum of current earnings }\end{array}$}} \\
\hline & \\
\hline $0.3689 \quad(0.2567)[0.1232]$ & $0.0774 \quad(0.1390)$ \\
\hline $0.0097 \quad(0.0080)[0.0032]$ & $0.0031 \quad(0.0046)$ \\
\hline $0.0262^{* * * *}(0.0086)[0.0087]$ & $0.0122^{* * *}(0.0050)$ \\
\hline $0.0490^{* * * *}(0.0069)[0.0163]$ & $0.0202^{* * *}(0.0031)$ \\
\hline $0.1329^{* * *}(0.0464)[0.0444]$ & $0.0651^{* * *}(0.0265)$ \\
\hline $0.1397^{* * *}(0.0475)[0.0466]$ & $0.0628^{* * *}(0.0271)$ \\
\hline$-0.0172 \quad(0.0212)[-0.0058]$ & $(0.0121)$ \\
\hline $0.0166(0.0220)[0.0056]$ & $(0.0126)$ \\
\hline \multicolumn{2}{|c|}{$\begin{array}{c}\text { Based on average past earnings specification (3-B 2) } \\
\text { Restrict effect of sum of average earnings }\end{array}$} \\
\hline $1.1700^{* * * * * *}(0.2926)[0.3981]$ & $0.6626^{* * * *}(0.1537)$ \\
\hline $0.2926^{* * *}(0.0271)[0.0996]$ & $0.1619^{* * *}(0.0148)$ \\
\hline \multicolumn{2}{|c|}{$\begin{array}{c}\text { Based on ratio of earnings specification (3-C 5) } \\
\text { with control for current earnings }\end{array}$} \\
\hline $0.5998^{*}(0.3558)[0.2002]$ & $0.3182 \quad(0.2001)$ \\
\hline $0.1656^{* * *}(0.0329)[0.0553]$ & $0.0878^{* * *}(0.0187)$ \\
\hline \multicolumn{2}{|c|}{ with control for average past earnings } \\
\hline $1.2523^{* * * *}(0.4088)[0.4262]$ & $0.6874^{* * * * * *}(0.2198)$ \\
\hline $0.3555^{* * *}(0.0493)[0.1174]$ & $0.1966^{* * *}(0.0256)$ \\
\hline \multicolumn{2}{|c|}{ (2) Two-stage estimation (incorrect standard errors) } \\
\hline \multicolumn{2}{|c|}{ Based on current earnings specification (3-A) } \\
\hline $0.5425^{* *}(0.2556)[0.1811]$ & $0.3080^{* * *}(0.1414)$ \\
\hline $0.0035(0.0081)[0.0012]$ & $(0.0047)$ \\
\hline $0.0273^{* * *}(0.0086)[0.0091]$ & $0.0137^{* * *}(0.0050)$ \\
\hline $0.0171^{* *}(0.0087)[0.0057]$ & $0.0113^{* *}(0.0050)$ \\
\hline $0.1330^{* * *}(0.0461)[0.0447]$ & $0.0651^{* *}(0.0267)$ \\
\hline $0.1186^{* * *}(0.0473)[0.0399]$ & $0.0479^{*} \quad(0.0272)$ \\
\hline$-0.0306 \quad(0.0212)[-0.0102]$ & $(0.0122)$ \\
\hline $0.0065(0.0219)[0.0022]$ & $0.0019 \quad(0.0127)$ \\
\hline \multicolumn{2}{|c|}{ Based on average past earnings specification (3-B 2) } \\
\hline & $0.2705^{*}$ \\
\hline
\end{tabular}

husband's decision-making power average household earnings

husband's decision-making power $\log$ (current household earnings)

husband's decision-making power $\log$ (average household earnings)

\section{Selected variables:}

husband's decision-making power age-50: husband wife

$\log$ (current household earnings)

long time horizon: husband wife

risk averse: husband wife

husband's decision-making power 


\begin{tabular}{l|c|c|}
\multirow{3}{*}{$\log ($ average household earnings) } & $0.3615^{* * *}(0.0480)[0.1230]$ & $0.2138^{* * *}(0.0270)$ \\
\cline { 2 - 3 } & \multicolumn{3}{|c|}{$\begin{array}{c}\text { Based on ratio of earnings specification }(3-C 5) \\
\text { with control for current earnings }\end{array}$} \\
\cline { 2 - 3 } husband's decision-making power & $0.7521^{* * * *}(0.2218)[0.2510]$ & $0.4098^{* * * *}(0.1248)$ \\
$\log$ (current household earnings) & $0.0246^{* * *}(0.0090)[0.0082]$ & $0.0154^{* * *}(0.0052)$ \\
\cline { 2 - 3 } & \multicolumn{3}{|c|}{ with control for average past earnings } \\
\cline { 2 - 3 } husband's decision-making power & $0.7928^{* * * *}(0.2532)[0.2698]$ & $0.4100^{* * * *}(0.1365)$ \\
$\log$ (average household earnings) & $0.3443^{* * * *}(0.0459)[0.1172]$ & $0.2004^{* * *}(0.0257)$ \\
\cline { 2 - 4 } & &
\end{tabular}

B. Use discrete information on reported decision-making power $y^{h}, y^{w}$

\begin{tabular}{|c|c|c|}
\hline \multirow{3}{*}{$\begin{array}{l}\text { husband reports: he has final say } \\
\text { "about equal" }\end{array}$} & \multicolumn{2}{|c|}{ (1) Information reported by husband } \\
\hline & $\begin{array}{c}0.1490 *(0.0827)[0.0505] \\
-0.0400(0.0765)[-0.0133]\end{array}$ & $\begin{array}{ll}0.1137^{* *} & (0.0473) \\
0.0069 & (0.0442) \\
\end{array}$ \\
\hline & \multicolumn{2}{|c|}{ (2) Information reported by wife } \\
\hline $\begin{array}{l}\text { wife reports: he has final say } \\
\text { "about equal" }\end{array}$ & $\begin{array}{ll}0.0791 & (0.0727)[0.0266] \\
0.0150 & (0.0675)[0.0050]\end{array}$ & $\begin{array}{ll}0.0473 & (0.0424) \\
0.0017 & (0.0397) \\
\end{array}$ \\
\hline
\end{tabular}

Data: Health and Retirement Study, 1992.

Sample: $\mathrm{N}=4237$ when current earnings are included or 3087 when average past earnings are included. Other control variables besides earnings are those reported in Table 3-A, along with subjective life expectancy. See text for more details. 


\section{RECENT WORKING PAPERS FROM THE \\ CENTER FOR RETIREMENT RESEARCH AT BOSTON COLLEGE}

Earnings and Women's Retirement Security

Alicia H. Munnell and Natalia Zhivan, June 2006

Mortality Heterogeneity and the Distributional Consequences of Mandatory

Annuitization

Guan Gong and Anthony Webb, June 2006

Can Heterogeneity of Populations Explain Differences in Mortality?

James W. Vaupel, Roland Rau, Carlo Giovanni Camarda and Kristin G. von Kistowski, March 2006

Personalized Retirement Advice and Managed Accounts: Who Uses Them and How Does Advice Affect Behavior in 401(k) Plans?

Julie Agnew, March 2006

Working for a Good Retirement

Barbara A. Butrica, Karen E. Smith and C. Eugene Steuerle, March 2006

The Politics of Parallel Pensions: Lessons from the United Kingdom for the United States

R. Kent Weaver, February 2006

Cross-National Evidence on the Fiscal Burden of Public and Private Finance of Old-Age Consumption

Gary Burtless, February 2006

The Effects of Population Aging on Labor Demand

Bob Triest, Steven Sass and Margarita Sapozhnikov, February 2006

Financing Disability Benefits in a System of Individual Accounts: Lessons from International Experience

Patrick Wiese, February 2006

Long-Term Immigration Projection Methods: Current Practice and How to Improve it

Neil Howe and Richard Jackson, February 2006

Policies to Promote Labor Force Participation of Older Workers

Alicia H. Munnell, January 2006

All working papers are available on the Center for Retirement Research website

(http://www.bc.edu/crr) and can be requested by e-mail (crr@bc.edu) or phone (617-552-1762). 